\title{
Review
}

\section{Notch and cancer: a double-edged sword}

\author{
U. Koch and F. Radtke*
}

The Swiss Institute for Experimental Cancer Research (ISREC), Ecole Polytechnique Fédérale de Lausanne (EPFL), Chemin des Boveresses 155, 1066 Epalinges (Switzerland), Fax: +41216526933, e-mail: Freddy.Radtke@isrec.ch

Received 2 April 2007; received after revision 29 June 2007; accepted 2 July 2007

Online First 11 August 2007

\begin{abstract}
The highly conserved Notch signaling pathway plays pleiotropic roles during embryonic development and is important for the regulation of selfrenewing tissues. The physiological functions of this signaling cascade range from stem cell maintenance and influencing cell fate decisions of barely differentiated progenitor cells, to the induction of terminal differentiation processes, all of which have been found to be recapitulated in different forms of cancers.
\end{abstract}

Although Notch signaling has mostly been associated with oncogenic and growth-promoting roles, depending on the tissue type it can also function as a tumor suppressor. Here we describe recent findings on Notch signaling in cancer and tumor angiogenesis, and highlight some of the therapeutic approaches that are currently being developed to interfere with tumor growth and progression.

Keywords. Notch signaling, oncogene, tumor suppressor, cancer, therapy.

\section{The Notch signaling cascade}

Notch genes encode evolutionarily conserved transmembrane bound receptors that are activated by two families of distinct but equally conserved transmembrane bound ligands [1]. Thus, Notch signaling is mediated via cell-to-cell contact. Mammals have four Notch receptors (Notch1-4) and five ligands named Delta-like (DLL) 1, 3 and 4 (homologues of Delta) and Jagged1 and 2, which are related to Drosophila Serrate. Notch receptors are synthesized as single precursor proteins that are cleaved (at site S1) during their transport to the cell surface by a furin-like protease $[2,3]$. They are expressed at the cell surface as heterodimers comprising an extracellular subunit $\left(\mathrm{N}^{\mathrm{EC}}\right)$, which is linked to a second subunit containing the extracellular heterodimerization domain fol-

* Corresponding author. lowed by a transmembrane domain and the cytoplasmic region of the receptors $\left(\mathrm{N}^{\mathrm{TM}}\right)$. The extracellular portions of Notch receptors contain 29-36 epidermal growth factor-like repeats implicated in ligand binding, followed by three cysteine-rich LIN12/Notch repeats that prevent ligand-independent signaling and a C-terminal hydrophobic region mediating heterodimerization between $\mathrm{N}^{\mathrm{EC}}$ and $\mathrm{N}^{\mathrm{TM}}$ [4]. The intracellular portion of $\mathrm{N}^{\mathrm{TM}}$ mediates cell signaling, and contains multiple conserved protein domains (Fig. 1).

Ligand-receptor interactions between two neighboring cells activate Notch signaling by the induction of two successive proteolytic cleavages. The first cleavage occurs extracellularly, close to the transmembrane domain (at site S2) and is mediated by a metalloprotease of the ADAM family [5,6]. This cleavage is most likely triggered by a physical 'tug' [7] as the ligands, together with $\mathrm{N}^{\mathrm{EC}}$ are subsequently endocytosed by the ligand-expressing cell [8]. A monoubi- 


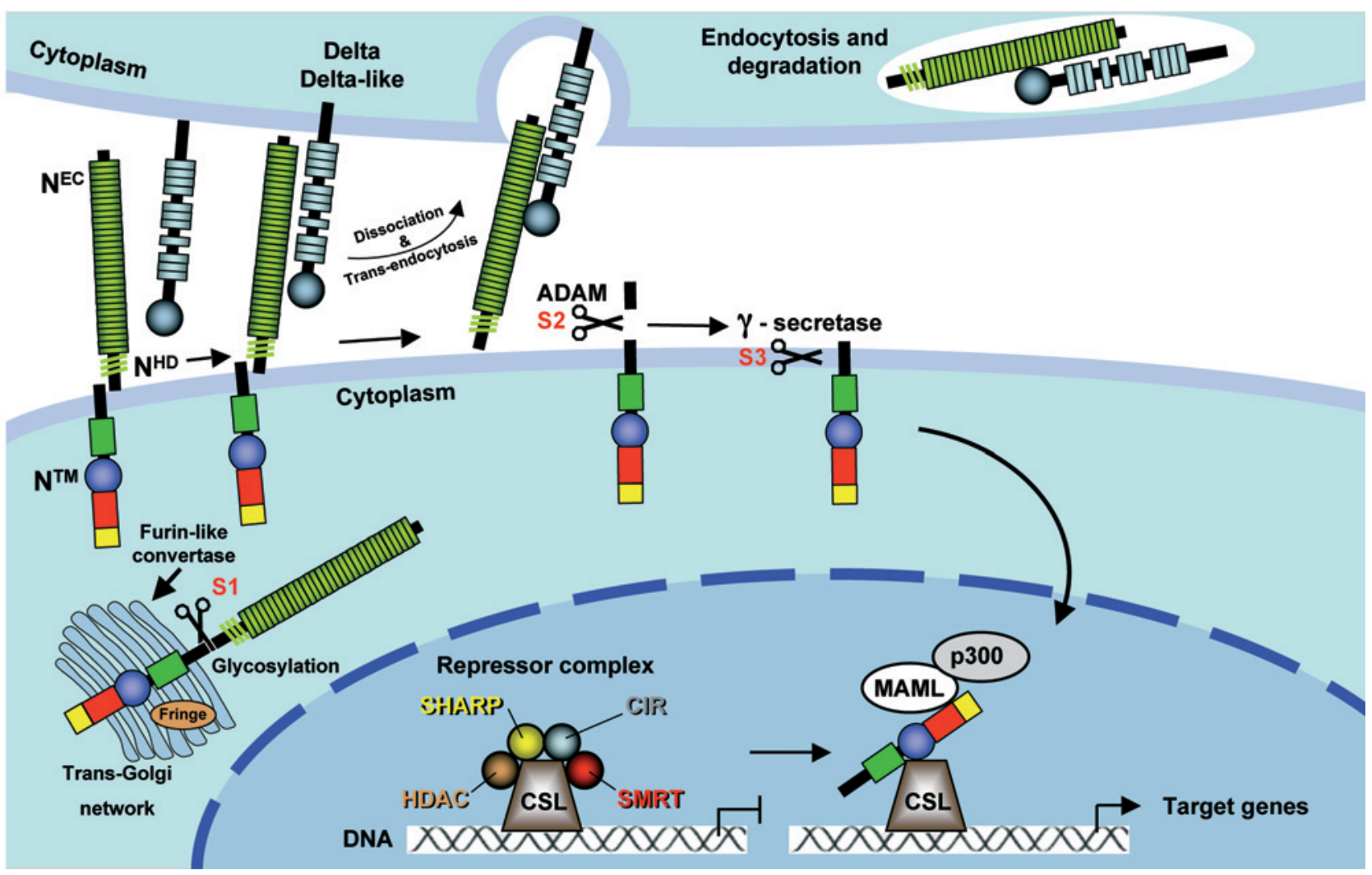

Figure 1. Notch signaling pathway. Notch receptors are synthesized as single precursor proteins, which are cleaved in the Golgi apparatus by a Furin-like convertase at site $\mathrm{S} 1$. Cleavage at site $\mathrm{S} 1$ during receptor maturation generates two non-covalently associated subunits $\left(\mathrm{N}^{\mathrm{EC}}\right.$ and $\mathrm{N}^{\mathrm{TM}}$ ). Notch signaling is initiated through ligand binding to the EGF-like repeats, which induces a second cleavage at site S2 by ADAMtype metalloproteases generating a short-lived intermediate $\mathrm{N}^{\mathrm{TM}}$. This cleavage is triggered by a physical 'tug' as the ligands, together with $\mathrm{N}^{\mathrm{EC}}$ are trans-endocytosed by the ligand-expressing cell. The third cleavage occurs at site S3 within the transmembrane domain and is mediated by $\gamma$-secretase, which releases NICD. NICD translocates into the nucleus and binds to the transcription factor CSL. This interaction leads to transcriptional activation by displacement of corepressors (HDAC, SHARP, CIR and SMRT) and simultaneous recruitment of coactivators including MAML and CBP/p300. EC, extracellular subunit; HD, heterodimerization domain; TM, transmembrane domain; NICD, cytoplasmic domain; HDAC, histone-deacetylase; CIR, CBF1-interacting corepressor; SMRT, silencing mediator of retinoid and thyroid receptors; SHARP, SMRT/HDAC-1-associated repressor protein; MAML, Mastermind-like proteins; CBP, CREB binding protein; CSL, CBF1 in humans, Suppressor of Hairless in Drosophila and LAG in C. elegans. Structure of NICD: green rectangle, RAM domain; blue circle, ANK repeats (seven iterated ankyrin-like repeats; red rectangle, TAD (transcriptional activation domain); yellow rectangle, PEST domain (proline, glutamate, serine and threonine-rich degradation sequence).

quitination process follows cleavage at the $\mathrm{S} 2$ site and eventually triggers the endocytosis-dependent $\gamma$-secretase-mediated cleavage within the transmembrane domain (at the S3 site) [9]. This process liberates the cytoplasmic domain (NICD), which subsequently translocates to the nucleus $[10,11]$. Once in the nucleus, NICD heterodimerizes with the transcription factor CSL (CBF-1 in humans, suppressor of hairless in Drosophila, Lag-1 in Caenorhabditis elegans, also known as RBP-J in mice) [12]. In the absence of Notch signaling, CSL functions as a transcriptional repressor by binding several co-repressors [13]. NICD converts CSL into a transcriptional activator by recruiting and binding co-activators including Mastermind-like proteins (MAML) [14, 15] and CBP/p300 [16] (Fig. 1). Among the best-known Notch target genes is the family of transcription factors known as Hairy en- hancer of split genes (Hes). Members of this family often negatively regulate the transcription of genes such as those of the achete scute gene family that are involved in neuronal differentiation [17]. The related HERP (Hes-related repressor protein) transcription factor family [18], the cell cycle regulator Cdkn1a [19], cyclin D1 [20], the gene for Notch-regulated ankyrin repeat protein (Nrarp) [21], Deltex1 [22], the pre $T$ cell receptor $\alpha$ gene [23], the ubiquitin ligase SKIP2 [24] and the proto-oncogene c-myc [25, 26] have all been identified as Notch target genes. This incomplete list of Notch target genes is likely to be extended, and appears to be context dependent. Although the Notch cascade is mechanistically relatively simple, the role of Notch signaling and the activation of downstream target genes in a given tissue is often unpredictable. With this outline of the Notch 
signaling pathway the stage is set to discuss its crucial role in various forms of cancer.

\section{Oncogenic functions of Notch in solid tumors}

\section{Notch and breast cancer}

The first data describing the oncogenic consequences of aberrant Notch signaling in solid tumors were derived from animal studies characterizing a frequent insertion site, named int3, of the mouse mammary tumor virus (MMTV) [27]. In contrast to retroviruses that carry oncogenes, MMTV induces mammary tumors by insertion into the genome and deregulating expression of adjacent genes. MMTV-deregulated genes are therefore referred to as "int" (integration) genes. The int 3 site was later identified as the Notch4 locus [28]. Integration of MMTV in this locus results in the LTR-driven expression of transcripts that encode a truncated version of the Notch4 receptor lacking most of the extracellular domain [29]. Transgenic mice expressing this truncated dominant active form of the Notch4/int3 gene under the control of mammary-specific regulatory elements confirmed a causative role of aberrant Notch signaling for the development of mammary tumors [30-32]. Microarray studies recently performed on Notch4/int3induced tumors identified high expression levels of c-kit and PDGFR. Treating these mice with the tyrosine kinase inhibitor Gleevec (Imatinib mesylate) resulted in decreased proliferation and angiogenesis, and in the induction of apoptosis within these mammary tumors. This indicated an oncogenic role for c-kit and PDGFR $\alpha$ tyrosine kinases in the context of int3 signaling [33].

Whether Notch4 plays a genuine role during normal mammary development is not clear. Gene targeted mice for Notch 4 show normal mammary gland development and normal lactation, suggesting that Notch4 is either not required for normal mammary development, or that another Notch family member compensates for loss of Notch4 function [21]. The role of Notch signaling during normal mammary development was recently investigated by conditional inactivation of the $R B P-J$ gene (encoding the transcriptional mediator of all Notch receptors) and the Pofut gene (encoding a fucosyltransferase gene, necessary for efficient ligand receptor binding). In the absence of either one of these genes a phenotype was only observed during pregnancy. The RBP-J-deficient secretory luminal cells acquired the characteristics of basal cells, and the myoepithelial cells showed excessive proliferation, resulting in disorganized alveolar structures. These results led to the interpretation that physiological Notch signaling during pregnancy maintains the luminal cell fate and prevents uncontrolled proliferation of basal cells [34].

MMTV insertions have also been found in the Notch1 locus, albeit with a lower frequency [35]. These insertions caused the expression of a truncated Notch1 protein similar to the case of int3. Transgenic mice expressing a Notch1-derived NICD under the control of the MMTV LTR develop noninvasive lactation-dependent papillary tumors that regress upon gland involution. However, after additional pregnancies, invasive tumors start to appear, most likely through the accumulation of secondary mutations [36]. Comparative expression profile analysis using microarrays led to the identification of the proto-oncogene $c-m y c$ as a direct target gene of Notch1-induced mammary tumors [25].

All these results on aberrant Notch signaling and mouse mammary tumorigenesis lead to the question of how significant aberrant Notch signaling is for human breast cancer. To date we have only correlative evidence for the involvement of Notch signaling in human breast cancer. Expression studies of NOTCH1 on ductal carcinoma in situ tumors showed positive NOTCH1 staining in approximately two thirds of the examined cases [37]. Approximately half of the NOTCH1-positive tumors were H-ras positive, and in vitro data suggested that $\mathrm{H}$-ras activity increases NOTCH1 signaling activity [37]. This seems to be important for the maintenance of the neoplastic phenotype in ras-transformed human cells. Interestingly, high levels of NOTCH1 and JAGGED1 expression correlate with poor survival of breast cancer patients [38]. Consistent with the murine data suggesting that c-myc is a direct downstream effector of Notch1, coexpression of NOTCH1 and c-MYC has been found in a large fraction of examined human breast cancers [39]. Additional evidence that aberrant Notch signaling might be of importance for human breast cancer is derived from studies on Numb, a negative regulator of the Notch cascade [40, 41]. Approximately $50 \%$ of the examined human mammary carcinomas, in particular the more aggressive forms, and most of the breast cancer cell lines exhibit loss of Numb expression. This finding correlated inversely with NICD expression and signaling as well with tumor grade and cell proliferation $[42,43]$. The inverse expression pattern of Numb and Notch might be caused by Notch negatively regulating Numb levels as recently suggested by Chapman and colleagues [44]. Although these findings are largely correlative, they strongly suggest that aberrant Notch signaling might be of great importance in human breast cancer. 


\section{Notch and medulloblastoma}

Medulloblastoma is the most common malignant brain tumor in childhood [45]. These primitive neuroectodermal tumors are thought to arise from neuronal stem or precursor cells of the ventricular zone and cerebellar external germinal layer [46]. Medulloblastomas have primarily been associated with aberrant sonic hedgehog signaling (Shh), which induces expression of N-MYC [47], a protein frequently overexpressed in these type of tumors [48] Increased activity of the Shh cascade in medulloblastomas was reported to be caused by inactivating mutations in Patched1 or Suppressor-of-Fused, two negative regulators of Shh signaling, as well as activating mutations in the Smoothened gene. Mutations in the Axin and $A P C$ genes causing increased activity of the Wnt pathway have also been identified in some medulloblastomas $[49,50]$. Until recently the Notch pathway was mechanistically not associated with the development of these tumors. However, the primitive nature of these tumor cells and the fact that Notch signaling is involved in the maintenance of neural stem and progenitor cells $[51,52]$ motivated several groups to investigate the potential role of Notch in medulloblastoma. Expression studies using primary medulloblastoma tumor samples showed increased mRNA expression of NOTCH2 but not of NOTCH1. In $15 \%$ of the examined tumors increased NOTCH2 expression levels were shown to result from $\mathrm{NOTCH} 2$ gene amplification. Moreover, increased expression of the target gene Hes1 in medulloblastomas correlated with a poor patient survival prognosis [53]. Increased expression of Notch2 and Hes5 has also been observed in a medulloblastoma mouse model based on the expression of a constitutively active form of the Smoothened gene in cerebellar granule neuron precursors [54]. These results suggest that Shh signaling can induce Notch signaling. Since Numb has recently been shown to function as a suppressor of hedgehog signaling [55] and Notch can negatively regulate Numb levels [44], it is tempting to speculate that Shh signaling in medulloblastoma activates the Notch cascade to escape a Numb-mediated regulatory loop, which would limit the extent and duration of hedgehog signaling.

Impediment of Notch signaling, either using $\gamma$-secretase inhibitors, soluble Delta ligands or siRNA approaches resulted in increased apoptosis and a pronounced reduction of viable cells in medulloblastoma cell lines and/or primary tumor cell cultures [53, 54]. Gain-of-function studies using a dominant active form of Notch2 promoted cell proliferation, soft agar colony formation and xenograft growth, whereas forced expression of Notch1 ICD (N1ICD) was growth inhibitory, suggesting that both Notch receptors exhibit distinct functions [53].

Accumulating evidence supports the concept that many cancer types harbor rare cell populations with stem cell-like properties, which are responsible for the propagation of tumor growth $[56,57]$. Markers such as CD133 and side population activity have been used to identify rare cells in brain tumors that have the unique ability to form tumor neurospheres and xenografts $[58,59]$. Interestingly, in this context a recent report shows that pharmacological inhibition of Notch signaling results in the depletion of a cancer stem cell-like population characterized by the expression of $\mathrm{CD}_{133^{+}}$and side population activity. More importantly, loss of Notch signaling within this cell population inhibited medulloblastoma growth both in vitro and in in vivo xenografts [60]. Although the results are very promising, additional genetic loss-of-function experiments in established tumors need to be performed to confirm that Notch signaling is actually required for the maintenance of these cancer stemlike cells.

\section{Notch and colorectal cancer}

In the intestine Notch signaling has been shown to be essential for the maintenance of the crypt compartment. Post-natal gut-specific inactivation of the CSL/ $R B P-J$ gene results in the complete loss of proliferating transient amplifying (TA) cells followed by their conversion into mucus-secreting goblet cells [61]. In reciprocal experiments expression of NICD in the gut inhibits differentiation of crypt progenitors [62]. The intestine of these transgenic mice consists mostly of undifferentiated TA cells. These reciprocal genetic loss- and gain-of-function data established a gatekeeper function of Notch for intestinal crypt progenitor cells in mice. These conclusions have been supported by toxicology studies of $\gamma$-secretase inhibitors (GSI), which are currently developed by pharmaceutical companies to inhibit the protease $(\gamma$ secretase) activity of presenilins for treatment of Alzheimer's disease. Rodents treated with GSI display unforeseen side effects, such as loss of proliferating TA cells accompanied by goblet cell metaplasia within the crypt compartment due to inhibition of Notch signaling $[63,64]$. This increase in goblet cell differentiation at the expense of enterocytes suggests an additional function for the Notch cascade in lineage specification of enterocytes, which is in agreement with the phenotype observed in gene targeted mice for the Hes 1 gene showing increased mucus-secreting and enteroendocrine cells at the expense of enterocytes [65]. A largely reciprocal phenotype, characterized by intestines only populated with enterocytes, is observed in gene-targeted mice for 
Math1, which is transcriptionally repressed by Hes1 [66]. Taken together these results point to at least two physiological functions for Notch; one is the maintenance of proliferating undifferentiated crypt progenitors and the other is to control binary cell fate decisions of progenitors that will differentiate into either the adsorptive or secretory lineage.

Another signaling cascade that is also of importance for the maintenance of the crypt progenitors is the Wnt pathway. Gut-specific inhibition of Wnt signaling results in the loss of the proliferative crypt compartment [67], suggesting that both the Notch and the Wnt cascades are necessary for normal gut homeostasis.

While the causative role of aberrant Wnt signaling for the development of colorectal cancer is well established [68], it is currently less clear whether Notch signaling might have a similar oncogenic function in the gut. The fact that gene expression profiles of crypt cells and colorectal cancer cell lines appear to be very similar suggest that colorectal cancer cells represent the transformed counter part of crypt cells [69]. Since Notch is a gate keeper of crypt cells, it is likely that Notch and Wnt signaling occur simultaneously in adenomas and crypt cells. Indeed, expression of the Notch target gene Hes 1 has been observed in adenomas of APC $^{\text {Min }}$ mice [61] as well as in primary human colorectal tumors [70]. Treatment of APC ${ }^{\text {Min }}$ mice with GSI partially induces goblet cell differentiation and reduces proliferation in such adenomas [61], suggesting that inhibition of Notch signaling can drive cells out of cycle and induce differentiation despite active Wnt signaling. The fact that not all of the adenoma cells can be differentiated might indicate that only early tumor stages are responsive to GSI, while later stages become resistant. Nevertheless, primary colorectal tumor samples and some colorectal cancer cell lines seem to express Hes1, suggesting that Notch target gene expression could be maintained through Notch signaling-independent mechanisms. Indeed, a recent report shows that Hes1 expression in colorectal tumor samples can be maintained through IKK activity via a chromatin-modifying mechanism. Importantly, pharmacological inhibition or expression of a dominant negative form of IKK $\alpha$ resulted in Notch target gene repression, which correlated with reduced tumor size in colorectal cancer xenografts [70]. These results indicate that maintenance of Notch target gene expression is of importance for tumor cell growth and can occur independently of Notch receptor signaling. This could explain, why only some adenoma cells are responsive to GSI. Further genetic loss- and gain-of-function approaches for Notch signaling molecules and/or target genes (such as Hes genes) need to be performed to show that Notch signaling is indeed important for the development or maintenance of colorectal tumors.

\section{Notch and pancreatic cancer}

An early feature of human pancreatic cancers is that they change their epithelial differentiation program. Many of the changes (including activation of the Notch cascade) documented in pathological situations are also observed during normal embryonic development of the pancreas. Notch signaling has been shown to play an important role during embryonic pancreas development maintaining an undifferentiated precursor cell type $[65,71,72]$. Notch receptors, ligands and downstream targets such as Hes 1 were found to be upregulated in pre-neoplastic lesions as well as in invasive pancreatic cancers in humans and mice [73-75], suggesting that Notch signaling in pancreatic cancers might be an early event leading to the accumulation of undifferentiated precursor cells. This notion was confirmed in explant cultures of adult mouse pancreas in which forced N1ICD expression induced a metaplastic conversion from an acinar cell-predominant epithelium to a ductal cellpredominant epithelium [73]. Transforming growth factor- $\alpha$ (TGF- $\alpha$ )-induced EGF receptor signaling is frequently found in pancreatic cancers [76]. Transgenic overexpression of TGF- $\alpha$ also results in acinarductal metaplasia, and correlated with increased Notch signaling. Interestingly, TGF- $\alpha$-induced metaplasia was abolished by pharmacological blockage of Notch signaling, indicating that Notch mediates TGF$\alpha$-induced changes in epithelial differentiation during early pancreatic tumorigenesis [73]. It is likely that elevated Notch signaling levels in the pancreas are not sufficient to generate neoplastic lesions, but it appears to be sufficient to generate immature pre-neoplastic lesions susceptible to additional mutations, which eventually might lead to the development of invasive ductal carcinoma.

\section{Notch and melanoma}

Melanomas are highly aggressive tumors, which originate from melanocytes deficient in growth control signals. Melanoma development and progression can be classified into several steps: (1) acquired and congenital nevi with normal melanocytes; (2) dysplastic nevi with atypic structure; (3) non-tumorigenic primary melanoma without metastatic competence (also known as radial growth phase); (4) tumorigenic primary melanoma with competence for metastasis (also known as vertical growth phase); and (5) metastatic melanoma [77]. Once melanomas start to metastasize they become refractory to conventional cancer therapy and have a mostly fatal outcome. 
Multiple aberrations due to inactivating and/or activating mutations in many signaling pathways have been found in melanoma, including loss of $\mathrm{p} 16^{\mathrm{INK} 4 \mathrm{a}}$ expression, which correlates with the invasive stage of melanoma progression $[78,79]$, activating mutations in B-raf [80] and N-ras [81], constitutive FGFreceptor signaling [82] and dysregulated Wnt signaling $[83,84]$.

Global gene expression profiling and immunohistochemistry revealing the expression of multiple Notch receptors and ligands in primary lesions of human malignant melanomas have extended the list of possible pathways involved in melanoma development [85-88]. Subsequent studies on established melanoma cell lines showed that blocking Notch signaling pharmacologically could have growth suppressive effects. However, constitutive activation of Notch promotes growth and survival and in certain experimental settings lung metastases in mice $[88,89]$. Forced expression of Notch signaling in particular seems to promote phase four of melanoma, while it has little effect on already metastatic melanoma cells. The oncogenic function of Notch signaling within these cell lines was linked to increased $\beta$-cateninmediated signaling [88], as well as to increased MAPK and AKT signaling [90]. Yet, how Notch signaling interacts with these pathways in melanoma cells is currently unclear. Although these studies suggest that aberrant Notch signaling can influence certain stages of melanoma, genetic loss-of-function experiments in established melanoma models need to be performed in the future to convincingly show that Notch is an obligate signaling cascade for melanoma development and/or tumor progression.

Nevertheless, such an essential role for Notch signaling has been shown for normal melanocyte development. Melanocyte-specific inactivation of the RBP-J gene, or simultaneous inactivation of Notch1 and Notch 2 resulted in defective hair pigmentation caused by loss of melanoctye progenitor and/or stem cells due to apoptosis [91, 92]. Transgenic expression of Hes1 in Notch signaling-deficient mice efficiently rescues melanocyte development, suggesting that Notch signaling is important for survival of melanocyte stem or progenitor cells [91].

\section{Notch and leukemia}

Historically, human NOTCH was identified at the chromosomal breakpoint of a subset of $\mathrm{T}$ cell lymphoblastic leukemias/lymphomas containing a $\mathrm{t}(7 ; 9)(\mathrm{q} 34 ; \mathrm{q} 34.3)$ chromosomal translocation [93]. The translocation fuses the 3' portion of NOTCH1 to the $T$ cell receptor $J \beta$ locus. This results in a truncated NOTCH1 protein (N1ICD), which is constitutively active and aberrantly expressed [93]. However, this seminal discovery did not reveal the full oncogenic potential of the truncated version of N1ICD. A causative role of Notch1 in T cell lymphomagenesis was only shown when Pear and colleagues [94] showed in a murine system that the overexpression of N1ICD using a retroviral transduction assay of hematopoietic stem cells led to immature $\mathrm{T}$ cell neoplasms. These and subsequent studies [95, 96] provided the initial basis for an experimental model whereby mutations in Notch1 have been analyzed for their onocgenic potential. This was shortly followed by studies with transgenic mice expressing dominantactive forms of Notch1 [22, 97, 98], by the identification of additional Notch1 rearrangements in mice with radiation-induced thymomas [99], and Notch1 mutations in murine transgenic models of T-ALL [100]. Despite the efficiency of Notch1 in inducing T-ALL in murine models, it became soon clear that the rare $t(7 ; 9)$ translocation event could account for only a minor fraction of T-ALL cases [101]. Ellisen et al. [93] originally screened $40 \mathrm{~T}$ cell leukemia/lymphoma patient samples and found 4 with the $t(7 ; 9)$ translocation. Based on this, an incidence of $\sim 10 \%$ was estimated. However, in subsequent studies, it appears that $<1 \%$ of all human $\mathrm{T}$ cell leukemias or lymphomas contain this translocation [101]. However, more importantly, aberrant Notch signaling was subsequently found in several human leukemias and lymphomas that lacked genomic rearrangements [102-104], signifying that upregulated Notch signaling might have a common role in human leukemogenesis. Jundt et al. [102] found high levels of NOTCH1 protein expression in $12 \mathrm{~T}$ cell anaplastic large cell lymphoma (ALCL) samples as compared to B cell lymphomas, and high levels of cleaved (activated) NOTCH1 were seen in 2 human ALCL-derived cell lines, compared to normal $\mathrm{T}$ cells. Furthermore, NOTCH3 was consistently expressed in a sample of 30 human $\mathrm{T}$ cell acute leukemias, and dramatically reduced levels were seen at clinical remission [103]. Interestingly, in T-ALL, Notch-3 is associated with the expression of its target gene, HES1, and of the gene encoding $\mathrm{pT} \alpha$ [103]. Expression of these three genes is normally limited to thymocytes and none is usually expressed in normal mature peripheral $\mathrm{T}$ cells. Thus, a T-ALL signature, resulting from the combined expression of NOTCH3, pT $\alpha$ and HES1, characterizes the active and relapsing disease. Intriguingly, in a study designed to identify NOTCH-1 downstream targets in T-ALL cells, NOTCH3 was one of the genes up-regulated by NOTCH1 in human T-ALL cell lines [26]. This could actually suggest that a combination of N1ICD and N3ICD may be important in the develop- 
ment of $\mathrm{T}$ cell leukemia. N3ICD could possibly function by activating NF- $\kappa \mathrm{B}$ via its recently described effect on IKK $\alpha$ [105]. Although these observations do not establish a causal role for Notch in these $\mathrm{T}$ cell malignancies, they suggest the possibility that upregulation of Notch may play a role in more than the small subset of lymphomas that have the $t(7 ; 9)$ translocation. More compelling evidence was brought about by a study published from the laboratory of Aifantis [106]. They analyzed the gene expression profile of primary hematopoietic stem and lymphocyte progenitor cells, as these are the cell populations where random Notch1 activating mutations initially occur. The analysis revealed that a panel of significantly up-regulated genes were components of the $\mathrm{NF}-\mathrm{\kappa B}$ pathway and included target genes such as $N f k b 2$, Relb, Nfkbia, Bcl2a1 and Ccr7. A direct link between the Notch and NF- $\mathrm{BB}$ pathway was provided using N1ICD to induce the activity of NF- $\mathrm{KB}$ reporters. Dominant negative forms of the MAML1 and $I k B \alpha$ genes, respectively, could efficiently antagonize these interactions. Conclusive evidence was provided in the same study showing that NOTCH1 human TALL derived mutations activate the NF- $\mathrm{BB}$ pathway and that T-ALL cell lines have an activated NF- $\mathrm{\kappa B}$ pathway. Definitive proof for a central role of NOTCH1 in human T-ALL came from a recent study identifying somatic activating mutations in the NOTCH1 receptor independent of the $t(7 ; 9)$ translocation, which were detected in more than $50 \%$ of human T-ALL cases [107]. Additionally, they are found in all previously defined T-ALL subtypes. One set of mutations destabilizes the Notch heterodimerization domain (HD) (gain-of-function mutations), probably facilitating ligand-independent pathway activation, whereas mutations that disrupt the intracellular PEST domain might function by increasing the half-life of transcriptionally active N1ICD [9]. In contrast to human T-ALL, HD mutations are rare and insertions/frameshift mutations in the PEST region of Notch1 predominate in mouse T-ALL models [100, 108-110]. However, the precise mechanism by which Notch1 induces T-ALL is not yet fully elucidated.

Several studies published recently have identified potential Notch target genes that may play a role in the oncogenic potential of Notch in the development and/ or maintenance of disease. One of these target genes may be the $E 2 A$ transcription factor. Lack of E2A predisposes mice to T-ALL. Lymphomas developing in $\mathrm{E}_{2} \mathrm{~A}^{-1-}$ mice were shown to be critically dependent on Notch signaling, and Notch1 promoted the survival and proliferation of these cells, in part through the induction of $\mathrm{pT} \alpha$ [110]. Reschly et al. [110] demonstrated that the $\mathrm{T}$ cell lymphomas accumulated mutations in or near the PEST domain, which mediates degradation of the active form of Notch1. Cell cycle-related genes have been identified to be candidates for Notch target genes in T cell malignancies. Numerous observations have linked Notch signaling to the cell cycle machinery, which are likely to correlate with the ability of Notch to function as an oncogene [94] or tumor suppressor gene [111]. Yet, a direct interaction between these two molecular pathways was first implicated by Sarmento et al. [24], revealing that the F-box protein, SKP2, serves to connect Notch1 activation with $\mathrm{p} 27^{\mathrm{Kip} 1}$ and $\mathrm{p} 21^{\mathrm{WAF} 1 / \mathrm{Cip} 1}$ regulation. Notch activation led to increased degradation of $\mathrm{p} 27^{\mathrm{Kip} 1}$ and $\mathrm{p} 21^{\mathrm{Cip} 1}$ and to enhanced G1-S transition. Although the work was done in nontransformed cell lines, it is possible that the capacity of Notch to induce SKP2 and to down-regulate p2 $7^{\text {Kip1 }}$ expression may constitute the basis of its oncogenic potential in T-ALL. Sicinska and co-workers [112] revealed that mice lacking cyclin D3 are resistant to leukemogenesis induced by N1ICD. Their results indicate that cyclin D3 is required for the Notch oncogenic pathway that signals through pre-TCR, as well as for the $\mathrm{p} 56^{\mathrm{LCK}}$ pathway that signals downstream of the pre-TCR [112]. Specifically, it was observed that mice lacking cyclin D3 are resistant to Notch-driven leukemias and show reduced susceptibility to $\mathrm{T}$ cell malignancies triggered by $\mathrm{p} 56^{\mathrm{LCK}}$ but remain fully susceptible to a pre-TCR-independent oncogenic pathway. In the context of $\mathrm{T}$ cell leukemias, it was demonstrated that suppression of $\mathrm{p} 53$ by Notch is an important event in the development of lymphoma and the activation of p53 mediates regression of disease [88]. Using a tetracycline-inducible model for N1ICD activation Beverly et al. [113] showed that Notch suppresses p53 in lymphomagenesis through repression of the ARF-mdm2-p53 tumor surveillance network. Although inactivation of the N1ICD transgene leads to tumor regression, $100 \%$ of the mice relapse within 6 weeks. Interestingly, the Notch transgene is reactivated in a majority of the relapsed tumors, indicating that there is a strong selective pressure to reacquire Notch activity. N1ICD has also been shown to directly repress p53 through an mdm2independent pathway, by inhibiting its activating phosphorylations as well as nuclear localization. Blockage of p53 by N1ICD mainly occurred through the mammalian target of rapamycin (mTOR) using phosphatidylinositol 3-kinase (PI3K)-Akt/protein kinase B (PKB) pathway as the mTOR inhibitor rapamycin abrogated N1ICD inhibition of p53 [114]. Another recent study also implicated several proteins in the mTOR pathway as targets of Notch signaling [74]. The mTOR pathway received activating signals from Notch and the simultaneous blockade of the mTOR and Notch pathway with small molecule 
inhibitors resulted in synergistic suppression of $\mathrm{T}$ ALL growth. One target gene that seems to be partially responsible for these effects is $c-M Y C$, a recently described NOTCH1 transcriptional target. Enforced expression of c-myc can fully rescue mTOR effectors from Notch withdrawal in a subset of T-ALL cell lines. This finding implicates c-myc as an intermediary that connects Notch to mTOR. Although c-myc was already earlier identified as a possible Notch target in hematopoietic stem cells [115] linking Notch responsiveness to a 200-bp element lying immediately 5' of the c-myc transcriptional start site, neither a direct association of Notch with this site nor its functional importance was revealed. Recently, several groups published data placing c-MYC as a direct downstream target of NOTCH1 that maintains growth of T-ALL cells. Weng and colleagues [26] used T-ALL cell lines that are susceptible to GSI and probed for genes regulated by NOTCH1 using gene expression profiling. Among the potential target genes identified were many known Notch targets such as Hes-1, Heyl and Deltex. However, $c-M Y C$ was additionally identified. $c-M Y C$ expression was directly correlated to N1ICD levels and ChIP analysis revealed $c-M Y C$ to be a direct target of NOTCH1. In a similar approach Palomero et al. [116] also identified NOTCH1 as a direct regulator of cell growth in human T-ALL cell lines and placed $c-M Y C$ as an immediate target gene regulated by NOTCH1 in T-ALL, highlighting the importance of this interaction in the pathogenesis of human cancer. They were able to elegantly show that the interaction of NOTCH1 and c-MYC is composed of a feed-forward-loop regulatory motif controlling leukemic cell growth. To specifically identify N1ICD target genes in mouse $\mathrm{T}$ cell leukemia, doxycyclineregulated N1ICD T-ALL cell lines were developed [117]. Several known Notch1 target genes and signaling pathways were induced, and consistent with the above studies $c-m y c$ was again identified as a direct Notch1 target gene in mouse leukemic cells. These data provide compelling evidence that c-myc is also a critical downstream effector of Notch in the development of $\mathrm{T}$ cell leukemia. The existence of a direct link between Notch and c-myc in T-ALL cell lines and normal thymocytes has therapeutic as well as basic implications. Most mutated Notch1 receptors found in T-ALL cells depend on $\gamma$-secretase to transmit signals $[107,118]$, and the withdrawal of $c-m y c$ transgene expression cures $\sim 50 \%$ of mice with T-ALL [119]. That the primary effect of Notch1 signals in TALL cells appears to be on proliferation and metabolism, rather than differentiation or survival, suggests the use of combinatorial therapies of Notch pathway inhibitors and other therapeutic agents. This could take the form of agents that also disrupt protein synthesis through independent mechanisms, or drugs that target parallel pathways, such as those that regulate cell survival directly.

\section{The flip side of the coin: Notch as a tumor suppressor}

Up to this point, we have exclusively described growth promoting or oncogenic roles of the Notch signaling pathway. In tissues in which Notch exhibits growth promoting functions, its physiological role is mostly associated with immature progenitor stages during development or tissue homeostasis. To allow terminal differentiation of progenitor cells Notch signaling often has to be down-regulated. However, instead of maintaining progenitor cells in an undifferentiated state, or influencing their cell fate decisions, in some tissues Notch can also induce differentiation, which is associated with growth suppression. The best-studied example is the role of Notch in the skin. In the murine epidermis Notch receptors and ligand expression is mostly confined to the suprabasal layers and not found in the less differentiated stem or TA cells [19]. In vitro data from both human and mouse keratinocytes suggest that Notch signaling induces differentiation, which is accompanied by cell cycle arrest $[19,120,121]$. In mouse keratinocytes, but not human keratinocytes, cell cycle arrest is induced by Notch1-mediated expression of the cell cycle regulator $\mathrm{p} 21^{\mathrm{WAF} 1 / \mathrm{Cip} 1}[19,122]$. Another property of Notch1 activation is the induction of early differentiation markers including Keratin1/10 and involucrin, and down-modulation of integrin expression [19]. Conditional inactivation of signaling components of the Notch cascade, including Notch1, RBP-J and Presenilin1 and 2 in mouse skin results in hyperproliferation of the skin, hair loss and epidermal cyst formation within less than 1 month [111,123-125]. Over time, Notch1-deficient animals develop spontaneous, highly vascularized basal cell carcinoma-like tumors. This tumor type in mouse and man is frequently associated with deregulated Shh signaling, and Notch1 deficiency in the mouse skin leads to increased Gli2 expression, which is a downstream component of the Shh pathway [111]. Another pathway that seems to be deregulated as a consequence of loss of Notch1 signaling in the skin is the Wnt cascade. Notch1 deficiency results in increased $\beta$-catenin-mediated signaling in hyperproliferative skin and primary tumor lesions, suggesting that Notch might suppress Wnt signaling in the skin [111]. Suppression of Wnt signaling by Notch seems to be mediated indirectly by increasing $\mathrm{p} 21^{\mathrm{WAF} 1 / \mathrm{Cip} 1}$ protein levels that subsequently bind to the Wnt4 
promoter together with the E2F-1 transcription factor to down-regulate Wnt4 expression [126].

Moreover, classical chemically induced carcinogenesis experiments showed that Notch1-deficient skin is more susceptible to developing skin cancers. As the carcinogen-induced mutation predominantly affects the HA-ras gene, it is possible that loss of Notch1 signaling results in cooperative oncogenic effects with activated ras. This possibility has been confirmed by showing that Notch1-deficient keratinocytes forced to express an activated ras gene, form aggressive squamous cell carcinomas (SCC) when injected subcutaneously into nude mice, while wild-type cells do not [111]. A more recent study showed that transgenic mice expressing a dominant negative form of MAML1, which inhibits Notch signaling mediated by all Notch receptors, develop SCC that are associated with the accumulation of nuclear $\beta$-catenin and cyclin D1 in tumor cells [127]. Since the mouse skin expresses Notch1 and Notch2, it is conceivable that the squamous cell phenotype of the tumors is the result of a complete block of Notch signaling, while basal cell carcinomas may occur when only Notch1 signaling is abolished. Future investigations will be necessary to clarify this issue. Taken together, the genetic mouse studies strongly suggest that Notch signaling exhibits tumor suppressive functions in the skin. This leads to the question of whether these studies are relevant, or indicative for human skin cancers. Consistent with the genetic data from genemanipulated mice is the finding that human basal cell carcinomas show reduced expression of NOTCH1, NOTCH2 and JAGGED1 [128]. A more recent report shows reduced expression of NOTCH1, NOTCH2 and HES1 in a panel of human oral and skin SCC cell lines, as well as in surgically excised SCCs from patients. Furthermore, suppression of Notch signaling in primary human keratinocytes that express an activated form of the ras gene is sufficient to cause aggressive SCC in xenograft models [129], similar to the above-mentioned studies with mouse keratinocytes [111]. Mechanistically, Notch1 seems to be a p53 target gene, which negatively regulates Rho GTPase effector genes that have previously been linked to tumorigenesis [130-132]. Additional work with human keratinocytes and primary tumor samples needs to be performed to further clarify the role of Notch signaling in the human epidermis and skin cancer lesions. Nevertheless, it seems very likely that Notch also functions in human skin as tumor a suppressor.

Other tissues or forms of cancer where Notch signaling is associated with growth suppressive functions are the prostatic epithelium [121], hepatocellular carcinoma [133], and small cell lung cancer [134, 135].
However, the growth inhibitory role of Notch has mainly (with the exception of the prostate) been suggested on the basis of activated Notch1 overexpression studies. Thus, further experiments are clearly needed in these tissues or cancer types to clarify whether Notch indeed has tumor suppressive functions.

\section{Notch and tumor angiogenesis}

As discussed above, Notch has been associated with both oncosuppressive and oncogenic roles, and Notch signaling has been shown to play an important part in various carcinomas. In adults, blood vessels in most organs are quiescent - except notably, during the growth of solid tumors, when otherwise specific embryonic signaling pathways direct new blood vessels to grow around and into the tumor. One important player in this process is the vascular endothelial growth factor (VEGF), which is a potent inducer of angiogenesis both in embryos and in tumors [136, 137]. The other key player involved in the regulation of embryonic and tumor vessel development is the family of Notch signaling components. Several genetic studies show the importance of Notch signaling in angiogenesis as a result of gain- or loss-of-function of Notch signaling components by either promoting or inhibiting angiogenesis. Mice deficient for a variety of these components, including Notch1, Notch1/Notch4, Jagged1, Dl11, Dll4, Hey1/Hey2, and Presenilins (PS1 and PS2) resulted in embryonic lethality with vascular remodeling defects $[138,139]$. Haploinsufficiency of Dll4 also resulted in embryonic lethality from severe vascular defects in mice [140]. Remarkably, endothelial cell-specific N4ICD and knockouts of either Notch1 or Notch1/Notch4 produced similar phenotypes [141]. This would imply that either excessive upor down-regulation of Notch signaling is detrimental to vascular development, and thus a narrow range of optimal expression seems to be essential. There is ample evidence that the relative expression levels of Notch on adjacent developing cells influence cell fate decisions, originally shown by a landmarking report of Heitzler and Simpson [142] in the developing nervous system of Drosophila. In their studies, wild-type cells adopted the epidermal fate (the secondary fate) when neighboring cells expressed lower Notch levels, but adopted the neural fate (the primary fate) when neighboring cells expressed higher Notch levels. Presumably, a feedback loop, such as that observed in Caenorhabditis elegans development [143], amplifies initial differences in the expression of Notch on neighboring cells. In the mammalian system elegant studies revealed that Notch haploinsufficiency result- 
ed in defined cell fate decisions during T cell development $[144,145]$. Observations by various other groups revealed haploinsufficiency of Notch receptors and ligands in a plethora of developing systems [21, 140, 146-149]. However, the key point in terms of vascular development is that the various Delta/Jagged-Notch pathway members are absolutely required at early stages of vascular development [149, 150]. Although Notch signaling has been shown to be indispensable during embryonic development [150, 151], recently several groups have identified the importance of Notch signaling in tumor angiogenesis. It has been reported that DLL4 mRNA is up-regulated in the vasculature of a xenografted human breast carcinoma cell line, in endogenous human tumors and following hypoxia [152]. However, the expression of DLL4 is restricted to certain areas of microvessels suggesting that there is finely tuned regulation of Notch signaling during angiogenesis. Patel et al. [153] demonstrated that DLL4 expression is up-regulated in clear cell renal cell carcinoma and is correlated with VEGF expression. Reduction of basal Dll4 levels in endothelial cells by siRNA led to the inhibition of multiple endothelial functions in vitro including proliferation, migration, and network formation, implying the potential role of this pathway in cancer. In a different study, VEGF induced the expression of NOTCH1 and DLL4 through the PI3K-Akt pathway in human arterial endothelial cells [154]. These studies suggest that pro-angiogenic factors activate Notch signaling to promote angiogenesis. Wang and colleagues [155] showed that tumor-associated growth factors stimulate the direct interaction between tumor cells and endothelial cells via mitogen-activating protein kinase (MAPK) and Notch signaling pathways, promoting tumor neovascularization and tumor growth in vivo. They nicely demonstrated that JAGGED1 is highly expressed in head and neck squamous cell carcinoma and is induced through the MAPK pathway. The elevated JAGGED1 expressions levels on tumor cells triggered Notch activation in neighboring endothelial cells and promoted network formation. The effect was abolished through GSI, soluble JAGGED1 treatment or dominant negative RBP-J $\kappa$ expression within the endothelial cells. These studies are inspiring as they provide the first causal link between Notch signaling and tumor angiogenesis.

Preliminary results suggest that Notch signaling may also play a role in breast cancer angiogenesis. NOTCH3 is highly expressed in the neovasculature of human breast tumors, suggesting a possible role for this receptor in blood vessel maintenance [156]. Estrogen-up-regulated JAGGED1 and NOTCH1 expression in both MCF7 and endothelial cells promoted sprouting in endothelial cells [157]. The same study also showed that NOTCH1-expressing breast cancer cells induce hypoxia inducible factor- $1 \alpha$ (HIF-1 $\alpha$ ). Other recent data suggest that HIF- $1 \alpha$ binds and stabilizes activated Notch1, leading to enhanced Notch signaling and that Notch signaling was required to maintain an undifferentiated state in stem cells under hypoxic conditions [158]. It would be interesting to examine the relevance of these findings in tumor cells and determine if exposing tumor cells or endothelial cells to hypoxic conditions affects N1ICD transcriptional activity and tumor angiogenesis.

A series of recent landmark papers have yielded a better insight into Notch function during the formation of blood vessels in both embryos and tumors [159-165]. These new studies [164, 165] identify a novel role for Notch/Dll4 signaling during vascular development and reveal the mechanism responsible for the vascular defects that result from reduced Notch signaling. Of particular interest is the common finding that inhibition of Notch signaling led to increased sprouting and branching of blood vessels. However, the experiments performed by Noguera-Troise et al. [159] as well as Rigway et al. [160] revealed that the administration of either neutralizing antibodies against Dll4, a recombinant form of the Dll4 protein that had been generated to block Dll4/Notch signaling or adenoviruses engineered to express Dll4-Fc inhibited the growth of several different solid tumors in mice. Although blocking of Dll4 increased the sprouting and branching of blood vessels, and led to a marked elevation in blood-vessel density in the tumors, assessment of the vascular network in these tumors revealed that the new vessels functioned inefficiently and were not connected functionally to the vascular network of the tumors. This led inadvertently to an overall inhibition of tumor growth. These promising data have unveiled a new drug target for disrupting tumor angiogenesis (see below for further discussion).

\section{Therapeutic approaches}

This review has highlighted an important role of the Notch signaling pathway in cancer development. Although the causative role of activated Notch in human carcinogenesis has only been demonstrated explicitly for human NOTCH1 in several cases of TALL, Notch receptors and ligands are often aberrantly expressed in a wide range of cancers and in tumorderived cell lines (see above). One approach that seems suitable is to target components of the Notch signaling pathway as a relevant option for cancer treatment. Thus, protein components of the Notch pathway - including receptor/ligand binding, release 
of NICD, interaction of NICD and specific downstream targets, as well as NICD protein stability - may provide suitable drug targets; some of these are already available and others are theoretically possible (Fig. 2).

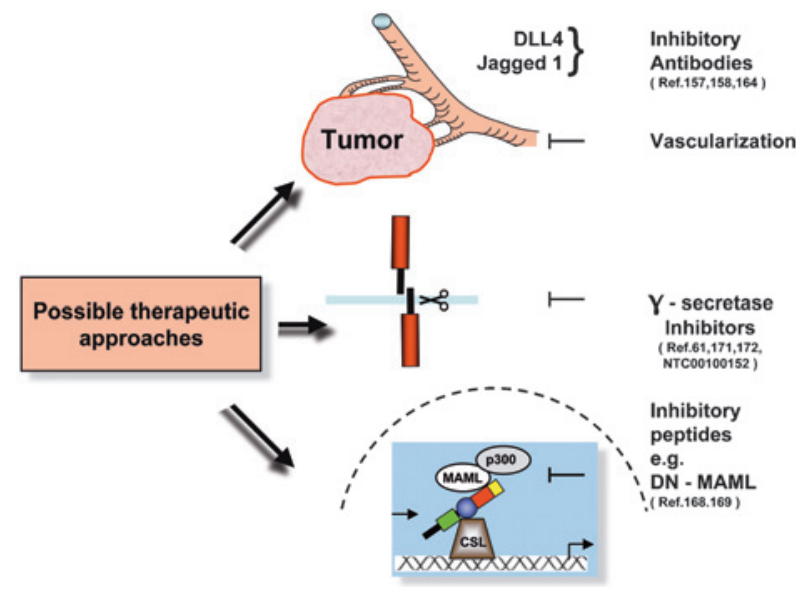

Figure 2. Therapeutic targets in Notch signaling. The Notch signaling pathway in various cancers can be targeted at various levels including receptor ligand binding, release of NICD as well as the coactivator complex. A promising strategy to block receptor ligand binding employs inhibitory antibodies directed against Jagged1 or DLL4 $[155,159,160]$. Blocking DLL4 led to dysfunctional neovascularization and inhibition of tumor growth. The most promising results have been achieved using small-molecule inhibitors of the $\gamma$-secretase complex (GSI), preventing the release of NICD $[61,172,173]$. A phase I clinical trial using the GSI MK0752 inhibitor was initiated in 2005 (http://www.clinicaltrials.gov/ct/ show/NCT00100152). The third protein component of the Notch signaling that may possibly provide a suitable drug target is the coactivator complex consisting of CSL, MAML and CBP/p300. Small inhibitory peptides acting as dominant negative forms of MAML or CLS decrease the transcriptional activation of target genes $[169,170]$.

Various strategies that have been used to inhibit Notch signaling aim at receptor ligand interactions. Studies targeting blood vessel formation employing blocking agents to Dll4 $[159,160]$ revealed substantial tumor growth reduction. Although, anti-Dll4 treatment inhibited tumor growth better when combined with antiVEGF treatment than when administered alone, the treatment with the Dll4 blockers was still effective against tumors that did not respond to anti-VEGF therapies. Thus, anti-Dll4 treatment may provide a good option for alternative or combinatorial therapy for solid tumors that are resistant to anti-VEGF. The findings of Wang and colleagues [155] highlight that tumor cells express Notch ligands that are able to stimulate tumor angiogenesis and tumor growth. Specific interruption of JAGGED1 signaling within human tumors may provide a potential novel antiangiogenic therapy.
Although various other strategies have been used to inhibit Notch signaling, including antisense Notch [166], RNA interference [53, 167], soluble receptor decoys that act by sequestering Notch ligands [166, 168] and dominant negative forms of MAML or CSL that decrease the transcriptional activation of target genes $[169,170]$, they are still far from actual therapeutic application. In practice, small-molecule inhibitors of the $\gamma$-secretase complex (GSI), which prevent the release of NICD represent the most immediately promising therapeutic approach in view of the current capabilities for the delivery of anticancer drugs. These agents simultaneously target all Notch receptors [171]. Promising results have been shown in vivo. One such study involved mice carrying a mutation in the APC tumor suppressor gene. These mice spontaneously develop intestinal adenomas overexpressing Notch target genes such as Hesl. Treatment with GSI down-regulated Hes1 and turned proliferative adenoma cells into goblet cells [61]. Kaposi sarcoma samples and cell lines markedly overexpress activated forms of NOTCH1, 2, 4 as well as Hey1 and Hey2 compared with normal endothelial cells. GSI treatment reduced Notch signaling and induced apoptosis in Kaposi sarcoma cells in vitro. In xenograft models of Kaposi sarcoma tumors, intra-tumoral injection of GSI inhibited tumor growth by decreasing proliferation and increasing apoptosis [172]. Several different GSI have been shown to reduce endothelial cell proliferation, tube formation and microvessel outgrowths in vitro. In mouse models of human glioblastomas and lung adenocarcinomas, both highly vascularized tumors, the GSI DAPT potently reduced tumor growth and vascularization [173]. However, most promising is a phase I clinical trial launched for relapsed or refractory T-ALL patients and advanced breast cancers (http://www.clinicaltrials.gov/ct/show/

\section{NCT00100152).}

Although, there seems to be quite a broad range of targeting Notch signaling in cancer therapeutics using GSI, a major challenge is the untoward side effects associated with these inhibitors, in particular the cytotoxicity in the gastrointestinal tract [174], which can be exacerbated by conventional chemotherapeutic drugs. Therefore, balancing efficacy and toxicity of GSI must be considered in future clinical applications. Acknowledgements. The authors thank Anne Wilson for critical reading of the manuscript and Pierre Dubied for preparation of the figures. We apologize to those colleagues whose work was not mentioned due to space limitations. The work was in part supported by, Swiss cancer league and the Swiss National Science Foundation. 
1 Artavanis-Tsakonas, S., Rand, M. D. and Lake, R. J. (1999) Notch signaling: cell fate control and signal integration in development. Science 284, $770-776$.

2 Logeat, F., Bessia, C., Brou, C., LeBail, O., Jarriault, S., Seidah, N. G. and Israel, A. (1998) The Notch1 receptor is cleaved constitutively by a furin-like convertase. Proc. Natl. Acad. Sci. USA 95, $8108-8112$.

3 Blaumueller, C. M., Qi, H., Zagouras, P. and ArtavanisTsakonas, S. (1997) Intracellular cleavage of Notch leads to a heterodimeric receptor on the plasma membrane. Cell 90, $281-291$

4 Sanchez-Irizarry, C., Carpenter, A. C., Weng, A. P., Pear, W. S., Aster, J. C. and Blacklow, S. C. (2004) Notch subunit heterodimerization and prevention of ligand-independent proteolytic activation depend, respectively, on a novel domain and the LNR repeats. Mol. Cell. Biol. 24, 9265 - 9273.

5 Brou, C., Logeat, F., Gupta, N., Bessia, C., LeBail, O., Doedens, J. R., Cumano, A., Roux, P., Black, R. A. and Israel, A. (2000) A novel proteolytic cleavage involved in Notch signaling: the role of the disintegrin-metalloprotease TACE. Mol. Cell 5, $207-216$.

6 Mumm, J. S., Schroeter, E. H., Saxena, M. T., Griesemer, A., Tian, X., Pan, D. J., Ray, W. J. and Kopan, R. (2000) A ligandinduced extracellular cleavage regulates gamma-secretaselike proteolytic activation of Notch1. Mol. Cell 5, $197-206$.

7 Nichols, J. T., Miyamoto, A., Olsen, S. L., D'Souza, B., Yao, C. and Weinmaster, G. (2007) DSL ligand endocytosis physically dissociates Notch1 heterodimers before activating proteolysis can occur. J. Cell Biol. 176, 445 - 458.

8 Parks, A. L., Klueg, K. M., Stout, J. R. and Muskavitch, M. A. (2000) Ligand endocytosis drives receptor dissociation and activation in the Notch pathway. Development 127, 1373 1385

9 Gupta-Rossi, N., Le Bail, O., Gonen, H., Brou, C., Logeat, F., Six, E., Ciechanover, A. and Israel, A. (2001) Functional interaction between SEL-10, an F-box protein, and the nuclear form of activated Notch1 receptor. J. Biol. Chem. 276, $34371-34378$.

10 Struhl, G. and Adachi, A. (1998) Nuclear access and action of notch in vivo. Cell 93, 649-660.

11 Schroeter, E. H., Kisslinger, J. A. and Kopan, R. (1998) Notch-1 signalling requires ligand-induced proteolytic release of intracellular domain. Nature 393, $382-386$.

12 Tamura, K., Taniguchi, Y., Minoguchi, S., Sakai, T., Tun, T., Furukawa, T. and Honjo, T. (1995) Physical interaction between a novel domain of the receptor Notch and the transcription factor RBP-J kappa/Su(H). Curr. Biol. 5, 1416 1423.

13 Lai, E. C. (2002) Keeping a good pathway down: transcriptional repression of Notch pathway target genes by CSL proteins. EMBO Rep. 3: 840 - 845.

14 Jeffries, S., Robbins, D. J. and Capobianco, A. J. (2002) Characterization of a high-molecular-weight Notch complex in the nucleus. Mol. Cell. Biol. 11, 3927 - 3941.

$15 \mathrm{Wu}$, L., Aster, J. C., Blacklow, S. C., Lake, R., ArtavanisTsakonas, S. and Griffin, J. D. (2000) MAML1, a human homologue of Drosophila mastermind, is a transcriptional. Nat. Genet. 4, $484-489$.

16 Fryer, C. J., Lamar, E., Turbachova, I., Kintner, C. and Jones, K. A. (2002) Mastermind mediates chromatin-specific transcription and turnover of the Notch enhancer complex. Genes Dev. 16, $1397-1411$.

17 Ishibashi, M. (2004) Molecular mechanisms for morphogenesis of the central nervous system in mammals. Anat. Sci. Int. 79, 226-234.

18 Iso, T., Kedes, L. and Hamamori, Y. (2003) HES and HERP families: multiple effectors of the Notch signaling pathway. J. Cell. Physiol. 194, 237 - 255.

19 Rangarajan, A., Talora, C., Okuyama, R., Nicolas, M. Mammucari, C., Oh, H., Aster, J. C., Krishna, S., Metzger, D., Chambon, P., Miele, L., Aguet, M. et al. (2001) Notch signaling is a direct determinant of keratinocyte growth arrest and entry into differentiation. EMBO J. 20, 3427 - 3436 .

20 Ronchini, C. and Capobianco, A. J. (2001) Induction of cyclin D1 transcription and CDK2 activity by Notch(ic): implication for cell cycle disruption in transformation by Notch(ic). Mol. Cell. Biol. 21, 5925 - 5934.

21 Krebs, L. T., Xue, Y., Norton, C. R., Shutter, J. R., Maguire, M., Sundberg, J. P., Gallahan, D., Closson, V., Kitajewski, J., Callahan, R., Smith, G. H., Stark, K. L. and Gridley, T. (2000) Notch signaling is essential for vascular morphogenesis in mice. Genes Dev. 14, 1343 - 1352.

22 Deftos, M. L., Huang, E., Ojala, E. W., Forbush, K. A. and Bevan, M. J. (2000) Notch1 signaling promotes the maturation of CD4 and CD8 SP thymocytes. Immunity 13, 73-84.

23 Reizis, B. and Leder, P. (2002) Direct induction of $\mathrm{T}$ lymphocyte-specific gene expression by the mammalian Notch signaling pathway. Genes Dev. 16, 295 - 300

24 Sarmento, L. M., Huang, H., Limon, A., Gordon, W., Fernandes, J., Tavares, M. J., Miele, L., Cardoso, A. A., Classon, M. and Carlesso, N. (2005) Notch1 modulates timing of G1-S progression by inducing SKP2 transcription and p27 Kip1 degradation. J. Exp. Med. 202, 157 - 168.

25 Klinakis, A., Szabolcs, M., Politi, K., Kiaris, H., ArtavanisTsakonas, S. and Efstratiadis, A. (2006) Myc is a Notch1 transcriptional target and a requisite for Notch1-induced mammary tumorigenesis in mice. Proc. Natl. Acad. Sci. USA 103, $9262-9267$.

26 Weng, A. P., Millholland, J. M., Yashiro-Ohtani, Y., Arcangeli, M. L., Lau, A., Wai, C., Del Bianco, C., Rodriguez, C. G., Sai, H., Tobias, J., Li, Y., Wolfe, M. S., Shachaf, C. et al. (2006) c-Myc is an important direct target of Notch1 in T-cell acute lymphoblastic leukemia/lymphoma. Genes Dev. 20, $2096-$ 2109.

27 Gallahan, D., Kozak, C. and Callahan, R. (1987) A new common integration region (int-3) for mouse mammary tumor virus on mouse chromosome 17. J. Virol. 61, 218 - 220.

28 Uyttendaele, H., Marazzi, G., Wu, G., Yan, Q., Sassoon, D. and Kitajewski, J. (1996) Notch4/int-3, a mammary protooncogene, is an endothelial cell-specific mammalian Notch gene. Development 122, 2251 - 2259.

29 Gallahan, D. and Callahan, R. (1997) The mouse mammary tumor associated gene INT3 is a unique member of the NOTCH gene family (NOTCH4). Oncogene 14, 1883-1890.

30 Jhappan, C., Gallahan, D., Stahle, C., Chu, E., Smith, G. H., Merlino, G. and Callahan, R. (1992) Expression of an activated Notch-related int-3 transgene interferes with cell differentiation and induces neoplastic transformation in mammary and salivary glands. Genes Dev. 6, 345 - 355 .

31 Gallahan, D., Jhappan, C., Robinson, G., Hennighausen, L., Sharp, R., Kordon, E., Callahan, R., Merlino, G. and Smith, G. H. (1996) Expression of a truncated Int3 gene in developing secretory mammary epithelium specifically retards lobular differentiation resulting in tumorigenesis. Cancer Res. 56, $1775-1785$.

32 Raafat, A., Bargo, S., Anver, M. R. and Callahan, R. (2004) Mammary development and tumorigenesis in mice expressing a truncated human Notch4/Int3 intracellular domain (hInt3sh). Oncogene 23, 9401 - 9407.

33 Raafat, A., Zoltan-Jones, A., Strizzi, L., Bargo, S., Kimura, K., Salomon, D. and Callahan, R. (2007) Kit and PDGFRalpha activities are necessary for Notch4/Int3-induced tumorigenesis. Oncogene 26, $662-672$.

34 Buono, K. D., Robinson, G. W., Martin, C., Shi, S., Stanley, P., Tanigaki, K., Honjo, T. and Hennighausen, L. (2006) The canonical Notch/RBP-J signaling pathway controls the balance of cell lineages in mammary epithelium during pregnancy. Dev. Biol. 293, 565 - 580.

35 Dievart, A., Beaulieu, N. and Jolicoeur, P. (1999) Involvement of Notch1 in the development of mouse mammary tumors. Oncogene 18, 5973 - 5981

36 Kiaris, H., Politi, K., Grimm, L. M., Szabolcs, M., Fisher, P., Efstratiadis, A. and Artavanis-Tsakonas, S. (2004) Modula- 
tion of notch signaling elicits signature tumors and inhibits hras1-induced oncogenesis in the mouse mammary epithelium. Am. J. Pathol. 165, 695 - 705.

37 Weijzen, S., Rizzo, P., Braid, M., Vaishnav, R., Jonkheer, S M., Zlobin, A., Osborne, B. A., Gottipati, S., Aster, J. C. Hahn, W. C., Rudolf, M., Siziopikou, K. et al. (2002) Activation of Notch-1 signaling maintains the neoplastic phenotype in human Ras-transformed cells. Nat. Med. 8, 979 - 986.

38 Reedijk, M., Odorcic, S., Chang, L., Zhang, H., Miller, N., McCready, D. R., Lockwood, G. and Egan, S. E. (2005) Highlevel coexpression of JAG1 and NOTCH1 is observed in human breast cancer and is associated with poor overall survival. Cancer Res. 65, 8530 - 8537.

39 Efstratiadis, A., Szabolcs, M. and Klinakis, A. (2007) Notch, Myc and breast cancer. Cell Cycle 6, $418-429$.

40 Jafar-Nejad, H., Norga, K. and Bellen, H. (2002) Numb: "Adapting" notch for endocytosis. Dev. Cell 3, 155- 156.

41 Roegiers, F. and Jan, Y. N. (2004) Asymmetric cell division. Curr. Opin. Cell Biol. 16, 195 - 205.

42 Pece, S., Serresi, M., Santolini, E., Capra, M., Hulleman, E. Galimberti, V., Zurrida, S., Maisonneuve, P., Viale, G. and Di Fiore, P. P. (2004) Loss of negative regulation by Numb over Notch is relevant to human breast carcinogenesis. J. Cell Biol. 167, 215 - 221.

43 Stylianou, S., Clarke, R. B. and Brennan, K. (2006) Aberrant activation of notch signaling in human breast cancer. Cancer Res. 66, $1517-1525$.

44 Chapman, G., Liu, L., Sahlgren, C., Dahlqvist, C. and Lendahl, U. (2006) High levels of Notch signaling downregulate Numb and Numblike. J. Cell Biol. 175, $535-540$.

45 Packer, R. J., Cogen, P., Vezina, G. and Rorke, L. B. (1999) Medulloblastoma: clinical and biologic aspects. Neurooncology $1,232-250$.

46 Oliver, T. G. and Wechsler-Reya, R. J. (2004) Getting at the root and stem of brain tumors. Neuron $42,885-888$.

47 Kenney, A. M., Cole, M. D. and Rowitch, D. H. (2003) Nmyc upregulation by sonic hedgehog signaling promotes proliferation in developing cerebellar granule neuron precursors. Development 130, $15-28$

48 Grotzer, M. A., Hogarty, M. D., Janss, A. J., Liu, X., Zhao, H., Eggert, A., Sutton, L. N., Rorke, L. B., Brodeur, G. M. and Phillips, P. C. (2001) MYC messenger RNA expression predicts survival outcome in childhood primitive neuroectodermal tumor/medulloblastoma. Clin. Cancer Res. 7, 2425 2433.

49 Dahmen, R. P., Koch, A., Denkhaus, D., Tonn, J. C., Sorensen, N., Berthold, F., Behrens, J., Birchmeier, W., Wiestler, O. D. and Pietsch, T. (2001) Deletions of AXIN1, a component of the WNT/wingless pathway, in sporadic medulloblastomas. Cancer Res. 61, 7039-7043.

50 Huang, H., Mahler-Araujo, B. M., Sankila, A., Chimelli, L., Yonekawa, Y., Kleihues, P. and Ohgaki, H. (2000) APC mutations in sporadic medulloblastomas. Am. J. Pathol. 156, $433-437$

51 Gaiano, N. and Fishell, G. (2002) The role of notch in promoting glial and neural stem cell fates. Annu. Rev. Neurosci. 25, $471-490$

52 Solecki, D. J., Liu, X. L., Tomoda, T., Fang, Y. and Hatten, M E. (2001) Activated Notch2 signaling inhibits differentiation of cerebellar granule neuron precursors by maintaining proliferation. Neuron $31,557-568$.

53 Fan, X., Mikolaenko, I., Elhassan, I., Ni, X., Wang, Y., Ball, D., Brat, D. J., Perry, A. and Eberhart, C. G. (2004) Notch1 and notch 2 have opposite effects on embryonal brain tumor growth. Cancer Res. 64, 7787 - 7793.

54 Hallahan, A. R., Pritchard, J. I., Hansen, S., Benson, M., Stoeck, J., Hatton, B. A., Russell, T. L., Ellenbogen, R. G., Bernstein, I. D., Beachy, P. A. and Olson, J. M. (2004) The SmoA1 mouse model reveals that notch signaling is critical for the growth and survival of sonic hedgehog-induced medulloblastomas. Cancer Res. 64, 7794 - 7800 .
55 Di Marcotullio, L., Ferretti, E., Greco, A., De Smaele, E., Po, A., Sico, M. A., Alimandi, M., Giannini, G., Maroder, M., Screpanti, I. and Gulino, A. (2006) Numb is a suppressor of Hedgehog signalling and targets Gli1 for Itch-dependent ubiquitination. Nat. Cell Biol. 8, $1415-1423$.

56 Singh, S. K., Clarke, I. D., Hide, T. and Dirks, P. B. (2004) Cancer stem cells in nervous system tumors. Oncogene 23 , $7267-7273$.

57 Wang, J. C. and Dick, J. E. (2005) Cancer stem cells: lessons from leukemia. Trends Cell Biol. 15, $494-501$.

58 Singh, S. K., Hawkins, C., Clarke, I. D., Squire, J. A., Bayani, J., Hide, T., Henkelman, R. M., Cusimano, M. D. and Dirks, P. B. (2004) Identification of human brain tumour initiating cells. Nature 432, 396 - 401.

59 Patrawala, L., Calhoun, T., Schneider-Broussard, R., Zhou, J., Claypool, K. and Tang, D. G. (2005) Side population is enriched in tumorigenic, stem-like cancer cells, whereas $\mathrm{ABCG} 2^{+}$and $\mathrm{ABCG} 2^{-}$cancer cells are similarly tumorigenic. Cancer Res. 65, 6207 - 6219.

60 Fan, X., Matsui, W., Khaki, L., Stearns, D., Chun, J., Li, Y. M. and Eberhart, C. G. (2006) Notch pathway inhibition depletes stem-like cells and blocks engraftment in embryonal brain tumors. Cancer Res. 66, 7445 - 7452.

61 van Es, J. H., van Gijn, M. E., Riccio, O., van den Born, M., Vooijs, M., Begthel, H., Cozijnsen, M., Robine, S., Winton, D. J., Radtke, F. and Clevers, H. (2005) Notch/gamma-secretase inhibition turns proliferative cells in intestinal crypts and adenomas into goblet cells. Nature 435, $959-963$.

62 Fre, S., Huyghe, M., Mourikis, P., Robine, S., Louvard, D. and Artavanis-Tsakonas, S. (2005) Notch signals control the fate of immature progenitor cells in the intestine. Nature 435, $964-968$.

63 Wong, G. T., Manfra, D., Poulet, F. M., Zhang, Q., Josien, H., Bara, T., Engstrom, L., Pinzon-Ortiz, M., Fine, J. S., Lee, H. J., Zhang, L., Higgins, G. A. and Parker, E. M. (2004) Chronic treatment with the gamma-secretase inhibitor LY-411,575 inhibits beta-amyloid peptide production and alters lymphopoiesis and intestinal cell differentiation. J. Biol. Chem. 279, $12876-12882$.

64 Milano, J., McKay, J., Dagenais, C., Foster-Brown, L., Pognan, F., Gadient, R., Jacobs, R. T., Zacco, A., Greenberg, B. and Ciaccio, P. J. (2004) Modulation of notch processing by gamma-secretase inhibitors causes intestinal goblet cell metaplasia and induction of genes known to specify gut secretory lineage differentiation. Toxicol. Sci. 82, $341-358$.

65 Jensen, J., Pedersen, E. E., Galante, P., Hald, J., Heller, R. S., Ishibashi, M., Kageyama, R., Guillemot, F., Serup, P. and Madsen, O. D. (2000) Control of endodermal endocrine development by Hes-1. Nat. Genet. 24, $36-44$.

66 Yang, Q., Bermingham, N. A., Finegold, M. J. and Zoghbi, H. Y. (2001) Requirement of Math1 for secretory cell lineage commitment in the mouse intestine. Science 294, 2155 - 2158.

67 Sancho, E., Batlle, E. and Clevers, H. (2004) Signaling pathways in intestinal development and cancer. Annu. Rev. Cell Dev. Biol. 20, 695 - 723.

68 Radtke, F. and Clevers, H. (2005) Self-renewal and cancer of the gut: two sides of a coin. Science 307, $1904-1909$.

69 van de Wetering, M., Sancho, E., Verweij, C., de Lau, W., Oving, I., Hurlstone, A., van der Horn, K., Batlle, E., Coudreuse, D., Haramis, A. P., Tjon-Pon-Fong, M., Moerer, P. et al. (2002) The beta-catenin/TCF-4 complex imposes a crypt progenitor phenotype on colorectal cancer cells. Cell 111, $241-250$.

70 Fernandez-Majada, V., Aguilera, C., Villanueva, A., Vilardell, F., Robert-Moreno, A., Aytes, A., Real, F. X., Capella, G., Mayo, M. W., Espinosa, L. and Bigas, A. (2007) Nuclear IKK activity leads to dysregulated notch-dependent gene expression in colorectal cancer. Proc. Natl. Acad. Sci. USA $104,276-281$.

71 Apelqvist, A., Li, H., Sommer, L., Beatus, P., Anderson, D. J., Honjo, T., Hrabe de Angelis, M., Lendahl, U. and Edlund, H. 
(1999) Notch signalling controls pancreatic cell differentiation. Nature 400, $877-881$.

72 Jensen, J., Heller, R. S., Funder-Nielsen, T., Pedersen, E. E., Lindsell, C., Weinmaster, G., Madsen, O. D. and Serup, P. (2000) Independent development of pancreatic alpha- and beta-cells from neurogenin3-expressing precursors: a role for the notch pathway in repression of premature differentiation. Diabetes 49, 163 - 176

73 Miyamoto, Y., Maitra, A., Ghosh, B., Zechner, U., Argani, P., Iacobuzio-Donahue, C. A., Sriuranpong, V., Iso, T., Meszoely, I. M., Wolfe, M. S., Hruban, R. H., Ball, D. W., Schmid, R. M. and Leach, S. D. (2003) Notch mediates TGF alpha-induced changes in epithelial differentiation during pancreatic tumorigenesis. Cancer Cell 3, 565 - 576.

74 Kimura, K., Satoh, K., Kanno, A., Hamada, S., Hirota, M. Endoh, M., Masamune, A. and Shimosegawa, T. (2007) Activation of Notch signaling in tumorigenesis of experimental pancreatic cancer induced by dimethylbenzanthracene in mice. Cancer Sci. 98, 155 - 162.

75 Hingorani, S. R., Petricoin, E. F., Maitra, A., Rajapakse, V., King, C., Jacobetz, M. A., Ross, S., Conrads, T. P., Veenstra, T D., Hitt, B. A., Kawaguchi, Y., Johann, D. et al. (2003) Preinvasive and invasive ductal pancreatic cancer and its early detection in the mouse. Cancer Cell 4, 437 - 450.

76 Hruban, R. H., Wilentz, R. E., Goggins, M., Offerhaus, G. J., Yeo, C. J. and Kern, S. E. (1999) Pathology of incipient pancreatic cancer. Ann. Oncol. 10 Suppl 4, 9-11.

77 Clark, W. H. (1991) Tumour progression and the nature of cancer. Br. J. Cancer 64, 631 - 644.

78 Reed, J. A., Loganzo, F. Jr., Shea, C. R., Walker, G. J., Flores, J. F., Glendening, J. M., Bogdany, J. K., Shiel, M. J., Haluska, F. G., Fountain, J. W. and Albino, A. P. (1995) Loss of expression of the p16/cyclin-dependent kinase inhibitor 2 tumor suppressor gene in melanocytic lesions correlates with invasive stage of tumor progression. Cancer Res. 55, 2713 2718.

79 Piccinin, S., Doglioni, C., Maestro, R., Vukosavljevic, T., Gasparotto, D., D’Orazi, C. and Boiocchi, M. (1997) p16/ CDKN2 and CDK4 gene mutations in sporadic melanoma development and progression. Int. J. Cancer 74, $26-30$.

80 Davies, H., Bignell, G. R., Cox, C., Stephens, P., Edkins, S., Clegg, S., Teague, J., Woffendin, H., Garnett, M. J., Bottomley, W., Davis, N., Dicks, E. et al. (2002) Mutations of the BRAF gene in human cancer. Nature 417, $949-954$.

81 Alsina, J., Gorsk, D. H., Germino, F. J., Shih, W., Lu, S. E., Zhang, Z. G., Yang, J. M., Hait, W. N. and Goydos, J. S. (2003) Detection of mutations in the mitogen-activated protein kinase pathway in human melanoma. Clin. Cancer Res. 9, $6419-6425$

82 Becker, D., Lee, P. L., Rodeck, U. and Herlyn, M. (1992) Inhibition of the fibroblast growth factor receptor 1 (FGFR1) gene in human melanocytes and malignant melanomas leads to inhibition of proliferation and signs indicative of differentiation. Oncogene 7, $2303-2313$.

83 Bittner, M., Meltzer, P., Chen, Y., Jiang, Y., Seftor, E. Hendrix, M., Radmacher, M., Simon, R., Yakhini, Z., BenDor, A., Sampas, N., Dougherty, E. et al. (2000) Molecular classification of cutaneous malignant melanoma by gene expression profiling. Nature 406, $536-540$.

84 Weeraratna, A. T., Jiang, Y., Hostetter, G., Rosenblatt, K., Duray, P., Bittner, M. and Trent, J. M. (2002) Wnt5a signaling directly affects cell motility and invasion of metastatic melanoma. Cancer Cell 1, 279 - 288.

85 Nickoloff, B. J., Osborne, B. A. and Miele, L. (2003) Notch signaling as a therapeutic target in cancer: a new approach to the development of cell fate modifying agents. Oncogene 22, $6598-6608$

86 Hoek, K., Rimm, D. L., Williams, K. R., Zhao, H., Ariyan, S., Lin, A., Kluger, H. M., Berger, A. J., Cheng, E., Trombetta, E. S., Wu, T., Niinobe, M. et al. (2004) Expression profiling reveals novel pathways in the transformation of melanocytes to melanomas. Cancer Res. 64, $5270-5282$.
87 Massi, D., Tarantini, F., Franchi, A., Paglierani, M., Di Serio, C., Pellerito, S., Leoncini, G., Cirino, G., Geppetti, P. and Santucci, M. (2006) Evidence for differential expression of Notch receptors and their ligands in melanocytic nevi and cutaneous malignant melanoma. Mod. Pathol. 19, 246 - 254.

88 Balint, K., Xiao, M., Pinnix, C. C., Soma, A., Veres, I., Juhasz, I., Brown, E. J., Capobianco, A. J., Herlyn, M. and Liu, Z. J. (2005) Activation of Notch1 signaling is required for betacatenin-mediated human primary melanoma progression. J. Clin. Invest. 115, $3166-3176$.

89 Nickoloff, B. J., Hendrix, M. J., Pollock, P. M., Trent, J. M., Miele, L. and Qin, J. Z. (2005) Notch and NOXA-related pathways in melanoma cells. J. Investig. Dermatol. Symp. Proc. 10, $95-104$.

90 Liu, Z. J., Xiao, M., Balint, K., Smalley, K. S., Brafford, P., Qiu, R., Pinnix, C. C., Li, X. and Herlyn, M. (2006) Notch1 signaling promotes primary melanoma progression by activating mitogen-activated protein kinase/phosphatidylinositol 3-kinase-Akt pathways and up-regulating $\mathrm{N}$-cadherin expression. Cancer Res. 66, 4182 - 4190.

91 Moriyama, M., Osawa, M., Mak, S. S., Ohtsuka, T., Yamamoto, N., Han, H., Delmas, V., Kageyama, R., Beermann, F., Larue, L. and Nishikawa, S. (2006) Notch signaling via Hes1 transcription factor maintains survival of melanoblasts and melanocyte stem cells. J. Cell Biol. 173, 333 - 339.

92 Schouwey, K., Delmas, V., Larue, L., Zimber-Strobl, U., Strobl, L. J., Radtke, F. and Beermann, F. (2007) Notch1 and Notch2 receptors influence progressive hair graying in a dosedependent manner. Dev. Dyn. 236, $282-289$.

93 Ellisen, L. W., Bird, J., West, D. C., Soreng, A. L., Reynolds, T. C., Smith, S. D. and Sklar, J. (1991) TAN-1, the human homolog of the Drosophila notch gene, is broken by chromosomal translocations in $\mathrm{T}$ lymphoblastic neoplasms. Cell 66, 649-661.

94 Pear, W. S., Aster, J. C., Scott, M. L., Hasserjian, R. P., Soffer, B., Sklar, J. and Baltimore, D. (1996) Exclusive development of $\mathrm{T}$ cell neoplasms in mice transplanted with bone marrow expressing activated Notch alleles. J. Exp. Med. 183, 2283 2291.

95 Aster, J. C., Xu, L., Karnell, F. G., Patriub, V., Pui, J. C. and Pear, W. S. (2000) Essential roles for ankyrin repeat and transactivation domains in induction of T-cell leukemia by notch1. Mol. Cell. Biol. 20, 7505 - 7515.

96 Allman, D., Karnell, F. G., Punt, J. A., Bakkour, S., Xu, L., Myung, P., Koretzky, G. A., Pui, J. C., Aster, J. C. and Pear, W. S. (2001) Separation of Notch1 promoted lineage commitment and expansion/transformation in developing T cells. J. Exp. Med. 194, 99 - 106.

97 Robey, E., Chang, D., Itano, A., Cado, D., Alexander, H., Lans, D., Weinmaster, G. and Salmon, P. (1996) An activated form of Notch influences the choice between CD4 and CD8 T cell lineages. Cell 87, $483-492$.

98 Fowlkes, B. J. and Robey, E. A. (2002) A reassessment of the effect of activated Notch1 on CD4 and CD8 T cell development. J. Immunol. 169, 1817 - 1821.

99 Tsuji, H., Ishii-Ohba, H., Ukai, H., Katsube, T. and Ogiu, T. (2003) Radiation-induced deletions in the 5' end region of Notch1 lead to the formation of truncated proteins and are involved in the development of mouse thymic lymphomas. Carcinogenesis 24, $1257-1268$.

100 O’Neil, J., Calvo, J., McKenna, K., Krishnamoorthy, V., Aster, J. C., Bassing, C. H., Alt, F. W., Kelliher, M. and Look, A. T. (2006) Activating Notch1 mutations in mouse models of T-ALL. Blood 107, $781-785$.

101 Ma, S. K., Wan, T. S. and Chan, L. C. (1999) Cytogenetics and molecular genetics of childhood leukemia. Hematol. Oncol. 17, $91-105$.

102 Jundt, F., Anagnostopoulos, I., Forster, R., Mathas, S., Stein, H. and Dorken, B. (2002) Activated Notch1 signaling promotes tumor cell proliferation and survival in Hodgkin and anaplastic large cell lymphoma. Blood 99, 3398 - 3403. 
103 Bellavia, D., Campese, A. F., Checquolo, S., Balestri, A. Biondi, A., Cazzaniga, G., Lendahl, U., Fehling, H. J., Hayday, A. C., Frati, L., von Boehmer, H., Gulino, A. and Screpanti, I. (2002) Combined expression of pTalpha and Notch3 in $\mathrm{T}$ cell leukemia identifies the requirement of preTCR for leukemogenesis. Proc. Natl. Acad. Sci. USA 99, $3788-3793$.

104 Chiaramonte, R., Calzavara, E., Balordi, F., Sabbadini, M., Capello, D., Gaidano, G., Serra, A., Comi, P. and Sherbet, G. V. (2003) Differential regulation of Notch signal transduction in leukaemia and lymphoma cells in culture. J. Cell Biochem. 88, $569-577$.

105 Vacca, A., Felli, M. P., Palermo, R., Di Mario, G., Calce, A., Di Giovine, M., Frati, L., Gulino, A. and Screpanti, I. (2006) Notch3 and pre-TCR interaction unveils distinct NF-kappaB pathways in T-cell development and leukemia. EMBO J. 25, $1000-1008$

106 Vilimas, T., Mascarenhas, J., Palomero, T., Mandal, M., Buonamici, S., Meng, F., Thompson, B., Spaulding, C. Macaroun, S., Alegre, M. L., Kee, B. L., Ferrando, A. Miele, L. and Aifantis, I. (2007) Targeting the NF-kappaB signaling pathway in Notch1-induced T-cell leukemia. Nat. Med. 13, $70-77$.

107 Weng, A. P., Ferrando, A. A., Lee, W., Morris, J. P. t., Silverman, L. B., Sanchez-Irizarry, C., Blacklow, S. C., Look, A. T. and Aster, J. C. (2004) Activating mutations of NOTCH1 in human T cell acute lymphoblastic leukemia. Science 306, 269 - 271.

108 Dumortier, A., Jeannet, R., Kirstetter, P., Kleinmann, E., Sellars, M., dos Santos, N. R., Thibault, C., Barths, J., Ghysdael, J., Punt, J. A., Kastner, P. and Chan, S. (2006) Notch activation is an early and critical event during T-Cell leukemogenesis in Ikaros-deficient mice. Mol. Cell. Biol. 26, $209-220$.

109 Lin, Y. W., Nichols, R. A., Letterio, J. J. and Aplan, P. D. (2006) Notch1 mutations are important for leukemic transformation in murine models of precursor-T leukemia/lymphoma. Blood 107, 2540 - 2543.

110 Reschly, E. J., Spaulding, C., Vilimas, T., Graham, W. V., Brumbaugh, R. L., Aifantis, I., Pear, W. S. and Kee, B. L. (2006) Notch1 promotes survival of E2A-deficient T cell lymphomas through pre- $\mathrm{T}$ cell receptor-dependent andindependent mechanisms. Blood 107, 4115 - 4121

111 Nicolas, M., Wolfer, A., Raj, K., Kummer, J. A., Mill, P., van Noort, M. Hui, C. C. Clevers, H., Dotto, G. P. and Radtke, F. (2003) Notch1 functions as a tumor suppressor in mouse skin. Nat. Genet. 33, $416-421$.

112 Sicinska, E., Aifantis, I., Le Cam, L., Swat, W., Borowski, C. Yu, Q., Ferrando, A. A., Levin, S. D., Geng, Y., von Boehmer, H. and Sicinski, P. (2003) Requirement for cyclin D3 in lymphocyte development and $\mathrm{T}$ cell leukemias. Cancer Cell 4 $451-461$.

113 Beverly, L. J., Felsher, D. W., Capobianco, A. J. (2005) Suppression of p53 by Notch in lymphomagenesis: implications for initiation and regression. Cancer Res. 65, 71597168

114 Mungamuri, S. K., Yang, X., Thor, A. D. and Somasundaram, K. (2006) Survival signaling by Notch1: Mammalian target of rapamycin (mTOR)-dependent inhibition of p53. Cancer Res. 66, $4715-4724$.

115 Satoh, Y., Matsumura, I., Tanaka, H., Ezoe, S., Sugahara, H., Mizuki, M., Shibayama, H., Ishiko, E., Ishiko, J., Nakajima, K. and Kanakura, Y. (2004) Roles for c-Myc in self-renewal of hematopoietic stem cells. J. Biol. Chem. 279, 24986 - 24993.

116 Palomero, T., Lim, W. K., Odom, D. T., Sulis, M. L., Real, P. J., Margolin, A., Barnes, K. C., O’Neil, J., Neuberg, D., Weng, A. P., Aster, J. C., Sigaux, F. et al. (2006) NOTCH1 directly regulates c-MYC and activates a feed-forward-loop transcriptional network promoting leukemic cell growth. Proc. Natl. Acad. Sci. USA 103, 18261 - 18266

117 Sharma, V. M., Calvo, J. A., Draheim, K. M., Cunningham, L. A., Hermance, N., Beverly, L., Krishnamoorthy, V., Bhasin,
M., Capobianco, A. J. and Kelliher, M. A. (2006) Notch1 contributes to mouse T-cell leukemia by directly inducing the expression of c-myc. Mol. Cell. Biol. 26, 8022 - 8031.

118 Malecki, M. J., Sanchez-Irizarry, C., Mitchell, J. L., Histen, G., $\mathrm{Xu}, \mathrm{M}$. L., Aster, J. C. and Blacklow, S. C. (2006) Leukemiaassociated mutations within the NOTCH1 heterodimerization domain fall into at least two distinct mechanistic classes. Mol. Cell. Biol. 26, 4642 - 4651

119 Felsher, D. W. and Bishop, J. M. (1999) Reversible tumorigenesis by MYC in hematopoietic lineages. Mol. Cell 4, 199 207.

120 Lowell, S., Jones, P., Le Roux, I., Dunne, J. and Watt, F. M. (2000) Stimulation of human epidermal differentiation by delta-notch signalling at the boundaries of stem-cell clusters. Curr. Biol. 10, 491 - 500 .

121 Nguyen, B. C., Lefort, K., Mandinova, A., Antonini, D., Devgan, V., Della Gatta, G., Koster, M. I., Zhang, Z., Wang, J., Tommasi di Vignano, A., Kitajewski, J., Chiorino, G. et al. (2006) Cross-regulation between Notch and p63 in keratinocyte commitment to differentiation. Genes Dev. 20, 1028 1042 .

122 Mammucari, C., Tommasi di Vignano, A., Sharov, A. A., Neilson, J., Havrda, M. C., Roop, D. R., Botchkarev, V. A., Crabtree, G. R. and Dotto, G. P. (2005) Integration of Notch 1 and calcineurin/NFAT signaling pathways in keratinocyte growth and differentiation control. Dev. Cell 8, 665-676.

123 Vauclair, S., Nicolas, M., Barrandon, Y. and Radtke, F. (2005) Notch1 is essential for postnatal hair follicle development and homeostasis. Dev. Biol. 284, $184-193$.

124 Yamamoto, N., Tanigaki, K., Han, H., Hiai, H. and Honjo, T. (2003) Notch/RBP-J signaling regulates epidermis/hair fate determination of hair follicular stem cells. Curr. Biol. 13, $333-338$

125 Pan, Y., Lin, M. H., Tian, X., Cheng, H. T., Gridley, T., Shen, J. and Kopan, R. (2004) gamma-secretase functions through Notch signaling to maintain skin appendages but is not required for their patterning or initial morphogenesis. Dev. Cell 7, $731-743$

126 Devgan, V., Mammucari, C., Millar, S. E., Brisken, C. and Dotto, G. P. (2005) p21WAF1/Cip1 is a negative transcriptional regulator of Wnt4 expression downstream of Notch1 activation. Genes Dev. 19, 1485 - 1495.

127 Proweller, A., Tu, L., Lepore, J. J., Cheng, L., Lu, M. M., Seykora, J., Millar, S. E., Pear, W. S. and Parmacek, M. S. (2006) Impaired notch signaling promotes de novo squamous cell carcinoma formation. Cancer Res. 66, 7438 - 7444.

128 Thelu, J., Rossio, P. and Favier, B. (2002) Notch signalling is linked to epidermal cell differentiation level in basal cell carcinoma, psoriasis and wound healing. BMC Dermatol. 2, 7 .

129 Lefort, K. and Dotto, G. P. (2004) Notch signaling in the integrated control of keratinocyte growth/differentiation and tumor suppression. Semin. Cancer Biol. 14, $374-386$.

130 Sahai, E. and Marshall, C. J. (2002) RHO-GTPases and cancer. Nat. Rev. Cancer 2, 133-142.

131 Benitah, S. A., Valeron, P. F., van Aelst, L., Marshall, C. J. and Lacal, J. C. (2004) Rho GTPases in human cancer: an unresolved link to upstream and downstream transcriptional regulation. Biochim. Biophys. Acta 1705, $121-132$.

132 Wilkinson, S., Paterson, H. F. and Marshall, C. J. (2005) Cdc42-MRCK and Rho-ROCK signalling cooperate in myosin phosphorylation and cell invasion. Nat. Cell Biol. 7,255261.

133 Qi, R., An, H., Yu, Y., Zhang, M., Liu, S., Xu, H., Guo, Z., Cheng, T. and Cao, X. (2003) Notch1 signaling inhibits growth of human hepatocellular carcinoma through induction of cell cycle arrest and apoptosis. Cancer Res. 63, 8323 - 8329 .

134 Sriuranpong, V., Borges, M. W., Ravi, R. K., Arnold, D. R., Nelkin, B. D., Baylin, S. B. and Ball, D. W. (2001) Notch signaling induces cell cycle arrest in small cell lung cancer cells. Cancer Res. 61, 3200 - 3205.

135 Sriuranpong, V., Borges, M. W., Strock, C. L., Nakakura, E. K., Watkins, D. N., Blaumueller, C. M., Nelkin, B. D. and Ball, 
D. W. (2002) Notch signaling induces rapid degradation of achaete-scute homolog 1. Mol. Cell. Biol. 22, 3129 - 3139.

136 Coultas, L., Chawengsaksophak, K. and Rossant, J. (2005) Endothelial cells and VEGF in vascular development. Nature 438, $937-945$.

137 Jain, R. K., Duda, D. G., Clark, J. W. and Loeffler, J. S. (2006) Lessons from phase III clinical trials on anti-VEGF therapy for cancer. Nat. Clin. Pract. Oncol. 3, $24-40$.

138 Iso, T., Hamamori, Y. and Kedes, L. (2003) Notch signaling in vascular development. Arterioscler. Thromb. Vasc. Biol. 23, $543-553$.

139 Li, J. L. and Harris, A. L. (2005) Notch signaling from tumor cells: a new mechanism of angiogenesis. Cancer Cell 8, 1-3.

140 Gale, N. W., Dominguez, M. G., Noguera, I., Pan, L., Hughes, V., Valenzuela, D. M., Murphy, A. J., Adams, N. C., Lin, H. C., Holash, J., Thurston, G. and Yancopoulos, G. D. (2004) Haploinsufficiency of delta-like 4 ligand results in embryonic lethality due to major defects in arterial and vascular development. Proc. Natl. Acad. Sci. USA 101, 15949 - 15954

141 Uyttendaele, H., Ho, J., Rossant, J. and Kitajewski, J. (2001) Vascular patterning defects associated with expression of activated Notch4 in embryonic endothelium. Proc. Natl. Acad. Sci. USA 98, 5643 - 5648.

142 Heitzler, P. and Simpson, P. (1991) The choice of cell fate in the epidermis of Drosophila. Cell 64, 1083 - 1092.

143 Wilkinson, H. A., Fitzgerald, K. and Greenwald, I. (1994) Reciprocal changes in expression of the receptor lin-12 and its ligand lag-2 prior to commitment in a C. elegans cell fate decision. Cell 79, $1187-1198$.

144 Washburn, T., Schweighoffer, E., Gridley, T., Chang, D. Fowlkes, B. J., Cado, D. and Robey, E. (1997) Notch activity influences the alphabeta versus gammadelta $\mathrm{T}$ cell lineage decision. Cell 88, 833-843.

145 Visan, I., Tan, J. B., Yuan, J. S., Harper, J. A., Koch, U. and Guidos, C. J. (2006) Regulation of T lymphopoiesis by Notch1 and Lunatic fringe-mediated competition for intrathymic niches. Nat. Immunol. 7, $634-643$.

146 Limbourg, F. P., Takeshita, K., Radtke, F., Bronson, R. T., Chin, M. T. and Liao, J. K. (2005) Essential role of endothelial Notch1 in angiogenesis. Circulation 111, 1826-1832.

147 Witt, C. M., Won, W. J., Hurez, V. and Klug, C. A. (2003) Notch2 haploinsufficiency results in diminished B1 B cells and a severe reduction in marginal zone B cells. J. Immunol. 171, $2783-2788$.

148 Cordes, R., Schuster-Gossler, K., Serth, K. and Gossler, A. (2004) Specification of vertebral identity is coupled to Notch signalling and the segmentation clock. Development 131, $1221-1233$.

149 Xue, Y., Gao, X., Lindsell, C. E., Norton, C. R., Chang, B., Hicks, C., Gendron-Maguire, M., Rand, E. B., Weinmaster, G. and Gridley, T. (1999) Embryonic lethality and vascular defects in mice lacking the Notch ligand Jagged1. Hum. Mol Genet. 8, 723-730.

150 Swiatek, P. J., Lindsell, C. E., del Amo, F. F., Weinmaster, G. and Gridley, T. (1994) Notch1 is essential for postimplantation development in mice. Genes Dev. 8, 707 - 719

151 Conlon, R. A., Reaume, A. G. and Rossant, J. (1995) Notch1 is required for the coordinate segmentation of somites. Development $121,1533-1545$.

152 Mailhos, C., Modlich, U., Lewis, J., Harris, A., Bicknell, R. and Ish-Horowicz, D. (2001) Delta4, an endothelial specific notch ligand expressed at sites of physiological and tumor angiogenesis. Differentiation 69, 135 - 144 .

153 Patel, N. S., Li, J. L., Generali, D., Poulsom, R., Cranston, D. W. and Harris, A. L. (2005) Up-regulation of delta-like 4 ligand in human tumor vasculature and the role of basal expression in endothelial cell function. Cancer Res. 65,8690 8697.

154 Liu, Z. J., Shirakawa, T., Li, Y., Soma, A., Oka, M., Dotto, G. P., Fairman, R. M., Velazquez, O. C. and Herlyn, M. (2003) Regulation of Notch1 and Dll4 by vascular endothelial growth factor in arterial endothelial cells: implications for modulat- ing arteriogenesis and angiogenesis. Mol. Cell. Biol. 23, 14 25.

155 Zeng, Q., Li, S., Chepeha, D. B., Giordano, T. J., Li, J., Zhang, H., Polverini, P. J., Nor, J., Kitajewski, J. and Wang, C. Y. (2005) Crosstalk between tumor and endothelial cells promotes tumor angiogenesis by MAPK activation of Notch signaling. Cancer Cell 8, 13 - 23.

156 Callahan, R. and Egan, S. E. (2004) Notch signaling in mammary development and oncogenesis. J. Mammary Gland Biol. Neoplasia 9, $145-163$.

157 Soares, R., Balogh, G., Guo, S., Gartner, F., Russo, J. and Schmitt, F. (2004) Evidence for the notch signaling pathway on the role of estrogen in angiogenesis. Mol. Endocrinol. 18, $2333-2343$.

158 Gustafsson, M. V., Zheng, X., Pereira, T., Gradin, K., Jin, S., Lundkvist, J., Ruas, J. L., Poellinger, L., Lendahl, U. and Bondesson, M. (2005) Hypoxia requires notch signaling to maintain the undifferentiated cell state. Dev. Cell 9, 617 - 628 .

159 Noguera-Troise, I., Daly, C., Papadopoulos, N. J., Coetzee, S., Boland, P., Gale, N. W., Lin, H. C., Yancopoulos, G. D. and Thurston, G. (2006) Blockade of Dll4 inhibits tumour growth by promoting non-productive angiogenesis. Nature 444, $1032-1037$.

160 Ridgway, J., Zhang, G., Wu, Y., Stawicki, S., Liang, W. C., Chanthery, Y., Kowalski, J., Watts, R. J., Callahan, C., Kasman, I., Singh, M., Chien, M. et al. (2006) Inhibition of Dll4 signalling inhibits tumour growth by deregulating angiogenesis. Nature 444, $1083-1087$.

161 Suchting, S., Freitas, C., le Noble, F., Benedito, R., Breant, C., Duarte, A. and Eichmann, A. (2007) The Notch ligand Deltalike 4 negatively regulates endothelial tip cell formation and vessel branching. Proc. Natl. Acad. Sci. USA 104, 3225 - 3230.

162 Lobov, I. B., Renard, R. A., Papadopoulos, N., Gale, N. W., Thurston, G., Yancopoulos, G. D. and Wiegand, S. J. (2007) Delta-like ligand 4 (Dll4) is induced by VEGF as a negative regulator of angiogenic sprouting. Proc. Natl. Acad. Sci. USA $104,3219-3224$.

163 Leslie, J. D., Ariza-McNaughton, L., Bermange, A. L., McAdow, R., Johnson, S. L. and Lewis, J. (2007) Endothelial signalling by the Notch ligand Delta-like 4 restricts angiogenesis. Development 134, 839 - 844.

164 Hellstrom, M., Phng, L. K., Hofmann, J. J., Wallgard, E., Coultas, L., Lindblom, P., Alva, J., Nilsson, A. K., Karlsson, L., Gaiano, N., Yoon, K., Rossant, J. et al. (2007) Dl14 signalling through Notch1 regulates formation of tip cells during angiogenesis. Nature 445, $776-780$.

165 Siekmann, A. F. and Lawson, N. D. (2007) Notch signalling limits angiogenic cell behaviour in developing zebrafish arteries. Nature $445,781-784$.

166 Garces, C., Ruiz-Hidalgo, M. J., Font de Mora, J., Park, C., Miele, L., Goldstein, J., Bonvini, E., Porras, A. and Laborda, J. (1997) Notch-1 controls the expression of fatty acidactivated transcription factors and is required for adipogenesis. J. Biol. Chem. 272, 29729 - 29734.

167 Purow, B. W., Haque, R. M., Noel, M. W., Su, Q., Burdick, M. J., Lee, J., Sundaresan, T., Pastorino, S., Park, J. K., Mikolaenko, I., Maric, D., Eberhart, C. G. and Fine, H. A. (2005) Expression of Notch-1 and its ligands, Delta-like-1 and Jagged-1, is critical for glioma cell survival and proliferation. Cancer Res. 65, 2353 - 2363.

168 Nickoloff, B. J., Qin, J. Z., Chaturvedi, V., Denning, M. F., Bonish, B. and Miele, L. (2002) Jagged-1 mediated activation of notch signaling induces complete maturation of human keratinocytes through NF-kappaB and PPARgamma. Cell Death Differ. 9, $842-855$.

169 Duncan, A. W., Rattis, F. M., DiMascio, L. N., Congdon, K. L., Pazianos, G., Zhao, C., Yoon, K., Cook, J. M., Willert, K., Gaiano, N. and Reya, T. (2005) Integration of Notch and Wnt signaling in hematopoietic stem cell maintenance. Nat. Immunol. 6, 314-322.

170 Weng, A. P., Nam, Y., Wolfe, M. S., Pear, W. S., Griffin, J. D., Blacklow, S. C. and Aster, J. C. (2003) Growth suppression of 
pre-T acute lymphoblastic leukemia cells by inhibition of notch signaling. Mol. Cell. Biol. 23, 655 - 664 .

171 Mizutani, T., Taniguchi, Y., Aoki, T., Hashimoto, N. and Honjo, T. (2001) Conservation of the biochemical mechanisms of signal transduction among mammalian Notch family members. Proc. Natl. Acad. Sci. USA 98, 9026 - 9031.

172 Curry, C. L., Reed, L. L., Golde, T. E., Miele, L., Nickoloff, B. J. and Foreman, K. E. (2005) Gamma secretase inhibitor blocks Notch activation and induces apoptosis in Kaposi's sarcoma tumor cells. Oncogene 24, 6333 - 6344.
173 Paris, D., Quadros, A., Patel, N., DelleDonne, A., Humphrey, J. and Mullan, M. (2005) Inhibition of angiogenesis and tumor growth by beta and gamma-secretase inhibitors. Eur. J. Pharmacol. 514, $1-15$.

174 Barten, D. M., Meredith, J. E., Jr., Zaczek, R., Houston, J. G. and Albright, C. F. (2006) Gamma-secretase inhibitors for Alzheimer's disease: balancing efficacy and toxicity. Drugs R D 7, $87-97$.

\section{To access this journal online: http://www.birkhauser.ch/CMLS}

